NBER WORKING PAPER SERIES

\title{
GRILICHESIAN BREAKTHROUGHS: INVENTIONS OF METHODS OF INVENTING AND FIRM ENTRY IN NANOTECHNOLOGY
}

\author{
Michael R. Darby \\ Lynne G. Zucker \\ Working Paper 9825 \\ http://www.nber.org/papers/w9825
NATIONAL BUREAU OF ECONOMIC RESEARCH
1050 Massachusetts Avenue
Cambridge, MA 02138
July 2003

This paper was initially prepared for the International Pre-Conference on "R\&D, Education and Productivity" in honor of Zvi Griliches (1930-1999) held at the NBER, Cambridge, MA, July 31, 2002. Zvi organized a NBER workshop for Zucker and Darby to present their first joint paper on biotechnology and was a constant source of ideas for improvement as their work progressed. We all stand on the shoulders of giants, and Zvi's shoulders are very high. This research has been supported by grants from the University of California's IndustryUniversity Cooperative Research Program, the University of California Systemwide Biotechnology Research and Education Program, the Japan Foundation, the National Science Foundation, and the Alfred P. Sloan Foundation through the NBER Research Program on Industrial Technology and Productivity. James R. Heath, Evelyn Hu, and Fraser Stoddart have provided continuing guidance as we try to understand nanoscale science and technology well enough to measure and model its growth and commercialization. Evelyn Hu's detailed comments particularly improved the paper, and members of the UCLA Innovation Workshop also provided useful comments. We are indebted to Luis Arias, Chuling Chen, Rui Wu, and Josh Mason for their work on the nanotechnology data and analysis. This paper is a part of the NBER's research program in Productivity. Any opinions expressed are those of the authors and not those of their employers or the National Bureau of Economic Research.

(C)2003 by Michael R. Darby and Lynne G. Zucker. All rights reserved. Short sections of text not to exceed two paragraphs, may be quoted without explicit permission provided that full credit including (C) notice, is given to the source. 
Grilichesian Breakthroughs: Inventions of Methods of Inventing and Firm Entry in Nanotechnology Michael R. Darby and Lynne G. Zucker

NBER Working Paper No. 9825

July 2003

JEL No. O31, L63, L65, M13, O16, R12

\section{$\underline{\text { ABSTRACT }}$}

Metamorphic progress (productivity growth much faster than average) is often driven by Grilichesian inventions of methods of inventing. For hybrid seed corn, the enabling invention was double-cross hybridization yielding highly productive seed corn that was not self-propagating. Biotechnology stemmed from recombinant DNA. Scanning probe microscopy is a key enabling discovery for nanotechnology. Nanotech publishing and patenting has grown phenomenally. Over half of nanotech authors are in the U.S. and 58 percent of those are in ten metropolitan areas. Like biotechnology, we find that firms enter nanotechnology where and when scientists are publishing breakthrough academic articles. A high average education level is also important, but the past level of venture-capital activity in a region is not. Breakthroughs in nanoscale science and engineering appear frequently to be transferred to industrial application with the active participation of discovering academic scientists. The need for top scientists' involvement provided important appropriability for biotechnology inventions, and a similar process appears to have started in nanotechnology.

Michael R. Darby

Cordner Professor of Money \& Financial Markets

Departments of Management, Economics, \& Policy Studies

Anderson Graduate School of Management University of California, Los Angeles

Los Angeles, CA 90095-1481

and NBER

darby@ucla.edu
Lynne G. Zucker

Professor of Sociology \& Policy Studies

Director, Center for International Science, Technology, and Cultural Policy, SPPSR

Department of Sociology

University of California, Los Angeles

Los Angeles, CA 90095-1551

and NBER

zucker@ucla.edu 


\title{
Grilichesian Breakthroughs: Inventions of Methods of Inventing and Firm Entry in Nanotechnology
}

\author{
by Michael R. Darby and Lynne G. Zucker
}

Zvi Griliches (1957a, 1957b) was the first economist to study the class of breakthrough discoveries which he named an "invention of a method of inventing." His case was hybrid corn, "a method of breeding superior corn for specific localities. It was not a single invention immediately adaptable everywhere." Griliches observed that such breakthroughs thus involve a doublediffusion process: the timing of application of the inventing method to specific potential products ("availability") and the speed with which sales of each specific product reach a mature level ("acceptance"). Griliches related the speed of both processes to their profitability.

This paper demonstrates that Grilichesian breakthroughs have a much wider applicability and importance than generally believed. In Darby and Zucker (2003), we argue that much if not most technological change occurs at any given time in the relatively few firms in the relatively few industries undergoing metamorphic progress. Modern biotechnology provides an excellent example of metamorphic progress based on an invention of a method of inventing. The invention in question was recombinant DNA (also known as genetic engineering or gene splicing) which has been applied since its 1973 invention to a widening range of scientific problems and products and industries. ${ }^{1} \quad$ The newer applications from the same breakthrough method are generally less profitable than the older applications as firms continue to pick fruit hanging ever higher on the tree of applications. However, the initial breakthrough often leads to virtuous circles of further scientific and technological productivity, making follow-on breakthroughs more likely (Zucker and Darby 1995). 
Nanoscale science and nanotechnology (hereafter nano S\&T) represent another such breakthrough invention of a method of inventing with the potential to drive technological progress. Nano S\&T involves understanding and control of matter and processes at the atomic and molecular level - building atom by atom (see Section II for a fuller definition). ${ }^{2}$ Nano S\&T is 15-20 years younger than biotechnology but so far following a similar growth trajectory. By beginning to study this technology now we hope to not only test and generalize findings by ourselves and others on the links between science and technology in biotechnology, semiconductors, lasers and other technologies, but to capture new elements of the metamorphic process which because of their ephemeral or ultimately unsuccessful existence cannot be captured in retrospective studies.

Section I of this paper lays out the key elements in Grilichesian breakthroughs that lead to metamorphic progress in existing and/or new industries; of particular interest is the neglected key element of the hybrid corn invention which made it profitable to apply to producing particular seed corns. Section II provides an introduction to the scientific, technological, and commercial aspects of nanoscale science and technology, with comparison to bioscience and biotechnology. Section III provides our initial empirical results demonstrating the close linkage between entry of firms into nanotechnology and the strength of the local science base, suggestive of natural excludability or other sources of knowledge localization. We lay out our conclusions on the general features of major Grilichesian breakthroughs and their application to nano S\&T in Section IV. A data appendix presents further detail on data sources and construction beyond that given in the text. 


\section{INVENTIONS OF METHODS OF INVENTING}

Before considering the special factors characteristic of an invention of a method of inventing, it is necessary to review and extend our common understanding of investment in research and development $(R \& D)$, highlighting elements which are crucial to Grilichesian breakthroughs.

\section{I.A. R\&D AS PURPOSIVE INVESTMENT}

Individuals and firms invest in R\&D in part motivated by the expected returns to and costs of the activity. Returns include above-normal profits for a variable time until entry drives returns to use of a planned or serendipitous invention to their normal equilibrium level, psychic returns to the scientists and engineers doing the $R \& D$, consumer surplus accruing to buyers from the inventor(s) and others enabled to produce by the invention, and producer surplus of competitors who are able to copy, invent around, or build upon the invention once it is observed. Inventor(s) or their employer(s) are motivated by only that portion of returns which are appropriable to them. The costs of an R\&D project are those that it takes to discover and/or apply the invention, prove its safety and effectiveness if necessary, and to move the invention from proof of principle or prototype to commercially producible. ${ }^{3}$ Properly taken, the expectations operator will allow for covariances among these returns or costs depending on the success or failure of the project.

Note first that the value of above-normal returns depends heavily - if an invention is successful enough that they initially exist - on how quickly the invention faces competition from frank imitators or sophisticated invent-arounders. These same processes occur in basic science as well as commercial applications. Most of the literature has focused on the formal intellectual 
property rights (such as patents, copyrights, and trade secrets) available to protect individual inventions. While patents are extraordinarily important for protecting particular biotech products, natural excludability provided important informal protection by slowing the diffusion of the requisite knowledge (Zucker and Darby 1996, Zucker, Darby, and Brewer 1998, Darby and Zucker 2003). Organizational boundaries and other social structure also served to limit the rate of diffusion (Zucker, Darby, Brewer, and Peng 1996).

Natural excludability arises from the fact that prior to adequate codification or incorporation into a commercially available instrument, cutting edge discoveries frequently involve extensive tacit knowledge that is embodied initially only in the discoverers and passed on by "learning by doing with" at the bench science level. Jensen and Thursby (2001) report that university technology transfer officers estimate that 70 percent of all university inventions cannot be licensed unless the inventors are willing to cooperate with the licensee in developing and transferring the technology. Mowery and Ziedonis (2001) show that market channels of university-to-firm technology transfer - particularly, exclusively licensed patents - are much more localized around the university than are non-market spillovers as evidenced by citations to university patents in other patents. Because the ongoing, active participation of inventing scientists in commercialization of most inchoate discoveries is necessary for the effort to succeed, we observe new high-tech industries growing up around universities and on commuting routes of leading scientists.

Ultimately codification or instrumentation may replace learning by doing with, but the returns to codifying processes such as textbook writing are low for some time relative to the commercial and scientific returns from applying very valuable breakthrough know-how directly (Zucker, Darby, and Armstrong 2002). Thus, for a significant period of time, typically measured 
in years, the top discovering scientists can realize extraordinary returns to commercializing their discoveries in the correct expectation that no competitor will enter to drive profits toward their competitive levels. Among the small number sharing the valuable knowledge the incentive is to find unique areas of application so long as the best next application has higher monopoly profits than the expected oligopoly profits from inventing a close substitute to any of the products commercialized by one of the other knowledgeable teams.

For individual scientists and engineers, the expected returns will include their psychic returns to doing good science and the pecuniary value that goes with enhanced professional reputation. This is especially true when we think of one of the entrepreneurial firms including one or more top university scientists among the founding principals. More generally, firms which permit or encourage scientists to follow their scientific tastes may well benefit from compensating wage differentials so that rational firm managers too may be influenced by the scientists' returns from doing good science (Zucker and Darby 1997). Zucker, Darby, and Torero (2002) find that star scientists at universities are more likely to begin working with firms after observing that other stars in the same region have increased publication and citation rates while working with firms. Firms that encourage creativity and scientific goals among their scientists arguably also are more likely to profit from scientists and engineers making and following up on serendipitous inventions. Darby and Zucker (2002) show that entrant firms with the deepest involvement of star scientists go public sooner and at a higher price.

\section{I.B. WAVES OF INVENTION AS A RESULT OF GRILICHESIAN BREAKTHROUGHS}

Schmookler (1966 and 1972) argued that technological progress in general and invention in particular are driven by the demand side - giving theoretical and empirical backing to the old 
chestnut, "Necessity is the mother of invention." More recently, the literature has emphasized technological opportunity and appropriability of returns as the two major factors varying across industries and explaining most variation in R\&D intensity (see Klevorick, Levin, Nelson, and Winter 1995). An invention of a method of inventing creates technological opportunity, appropriability, or both across a wide range of potential products.

Platform Technologies. Consider a platform technology like Sun Microsystems's $\mathrm{Java}^{\mathrm{TM}}$ which Sun makes freely available to software developers. Because software applications written in Java ${ }^{\mathrm{TM}}$ can run on any platform, Java ${ }^{\mathrm{TM}}$ creates a technological opportunity to write one program and satisfy many markets. However, this universality also reduces the appropriability of returns to inventing a new program since it can no longer be written for a particular niche and be protected from those unfamiliar with the peculiarities of that program. $\mathrm{Java}^{\mathrm{TM}}$ has diffused but no one except for Sun Microsystems which sells complementary products has made exceptional profits from it. ${ }^{4}$

Griliches's Case of Hybrid Seed Corn. As noted earlier, Griliches (1957b) examined the double diffusion process: the order in which the many hybrid seed corns were introduced and both the eventual market share of each type of seed corn and how rapidly that share was reached. Griliches looked at hybrid seeds for different growing regions as different products as the seed that had the highest expected output in one growing area might be inferior in another area. Thus different seeds had to be developed for each and localization of demand should not be confused with the localization of production and especially of $R \& D$ to create the inventions for each product. If all diabetics lived in Chicago, we would expect Genentech's human insulin to be sold exclusively in that region while anti-tubercular agents might be sold only in Arizona. There would be little to remark on if a California company chose to invent and market those products 
in Chicago and Arizona, respectively. Similarly, hybrid seed corn companies would logically try to develop winning varieties for the biggest corn markets regardless of where the seed company happened to be headquartered.

For years the authors have taught the classic Griliches (1958b) article, understanding that the founding invention was a method which produced superior hybrid corn compared to what could be produced by standard selection and propagation of high yield plants. As far as we can tell from footnote 3 in Griliches (1957b) and from his other writings on hybrid corn (1957a, $1958,1960 \mathrm{a}, 1960 \mathrm{~b}, 1980)$ that is what he understood to be the facts.

Curiously, Griliches's case appears to be a rare one in which the invention of a method of inventing was valuable because the method produced less valuable products than were possible by previous methods but products with a deficiency that increased appropriability sufficiently that private firms were willing to invest in the large, multiyear R\&D projects required to develop each product.

The precise invention is made clear in the original treatise by Edward East and Donald Jones (1919, pp. 221-224): ${ }^{5}$ You start with four different inbred varieties of corn A, B, C, and D. These strains themselves are not suitable for sale as seed because the inbreeding process reduces their vigor while ensuring certain characteristics valuable under particular growing conditions. On average, the first generation of each of the possible crosses is better than either parent and, more importantly, equal or better in yield but still inferior in resistance to the openpollination varieties then commonly used by farmers. The trick comes in crossing two of these first generation hybrids, for example $\mathrm{AxB}$ with $\mathrm{CxD}$. Depending on the particular inbred lines represented by A, B, C, and D, the resulting first generation double-cross hybrid can predictably deliver hardier plants with substantially higher yield than any of the inbred or open-pollination 
varieties in the public domain. Obviously, with dozens of inbred lines available and the opportunity to selectively breed more, the multi-year experimentation involved to find the best choices of $\mathrm{A}, \mathrm{B}, \mathrm{C}$, and $\mathrm{D}$ for a particular growing region is a costly $\mathrm{R} \& \mathrm{D}$ investment. Not surprisingly, by 1994 nearly 94 percent of researchers with doctorates breeding new corn lines were in industry and only 6 percent in academe or elsewhere in the public sector: "there are more $\mathrm{Ph} . \mathrm{D}$. corn breeders in any of the large corn breeding companies than all the public corn breeders combined in the U.S. and Canada." (Kannenberg 1999)

Lewontin (1993, pp. 52-57) argues that what was important was that the double-cross hybrid method produced a superior seed corn which itself did not breed true. If a farmer were to save some of his crop as seed for next year, he would have a mixture of inferior and high yield strains yielding far less per acre than the purchased seed. He/she would be willing to pay up to the value of the difference in productivity to obtain new pure hybrid seed corn from the growers.

Thus the essential value of East and Jones's discoveries 1918-1924 is this: Commercial $R \& D$ to develop hybrid seed corn now could be profitable since the seed would not be in direct competition with crops of prior years' purchasers. Lewontin (1992, p. 55) quotes the inventors to show their self-awareness of this property:

[Double-cross hybridization is] something that might easily be taken up by the seedsmen; in fact, it is the first time in agricultural history that a seedsman is enabled to gain the full benefit from a desirable origination of his own or something that he has purchased. The man who originates devices to open our boxes of shoe polish or to autograph our camera negatives, is able to patent his product and gain the full reward for his inventiveness. The man who originates a new plant which may be of incalculable benefit to the whole country gets nothing - not even fame - 
for his pains, as the plants can be propagated by anyone. There is correspondingly less incentive for the production of improved types. The utilization of the first generation hybrids enables the originator to keep the parental types and give out only the crossed seeds, which are less valuable for continued propagation.

- East and Jones (1919, p. 224, italicized portion omitted by Lewontin)

The inventors of double-cross hybrids seem to understand the positive social value of appropriability better than Lewontin.

The scientist-entrepreneur (later politician) Henry A. Wallace perceived the opportunity and established the first hybrid-seed-corn company Hi-Bred Corn Company (later Pioneer HiBred) in $1926 .{ }^{6}$ Experimentally trying each possible combination of two pairs from 30, 40, or more inbred lines and then testing each combination in each growing region would be an extraordinarily expensive proposition. The best corn breeders had a sufficient implicit model of what would work to order the pairs tried well enough that the cost of experimentation was low enough for seed companies to prosper. Purposive entry of competitors is possible, but only if the price for a particular seed corn is high enough to encourage duplicative invention knowing that the duopoly price will be lower than the monopoly price (Gilbert and Newbery 1982).

Biotechnology. The founding discovery for biotechnology occurred in 1973 when Stanley Cohen (of Stanford) and Herbert Boyer (of UCSF) realized that by combining their methods they could cut a desirable gene from one organism and insert into another organism to create a new organism which could reproduce itself with the new desired trait. ${ }^{7}$ Herbert Boyer with the support of venture capitalist co-founder Robert Swanson - led Genentech to the successful production in 1982 of human insulin from genetically engineered bacteria. Genetic engineering created not only a vast opening of technological opportunities across a range of 
products and industries, but also came with natural excludability. Scientists in the field agree that - like playing the violin - you learned genetic engineering by working with someone who knew how to do it. Even today new authors on an article reporting a new genetic sequence discovery are normally coauthors of other scientists who have already appeared on such an article (Zucker, Darby, and Torero 2002). In the early days, that meant that the essential input for the technology were one or more of the people who could do it. When the U.S. Supreme Court in 1980 approved patenting of life forms created by genetic engineering, appropriability was further enhanced.

\section{I.C. ESSENTIAL ELEMENTS OF SUCCESFUL GRILICHESIAN BREAKTHROUGHS}

We believe it is possible to identify a successful invention of a method of inventing before it is proven over time by examining whether if creates appropriable technological opportunity across a broad range of products. The double crossing of pure inbred corn lines created the private incentive to develop new seed lines because the corn grown from the seed was markedly inferior in output if used as a seed for a second generation of corn. The major biotech firms nearly all had as founders or initial key scientists top "star" discovering scientists who had access to the scarce tacit knowledge needed to take advantage of the new technological opportunities. 


\section{NANOTECHNOLOGY: A VERY BIG, VERY SMALL THING}

The U.S. government has identified nano $\mathrm{S} \& \mathrm{~T}$ as a scientific and technological opportunity of immense potential, formally launching a National Nanotechnology Initiative (NNI) in January 2000. It is extremely difficult to define simply the full range of nano S\&T, but the NNI's steering committee settled on the following definition of nanotechnology:

Research and technology development at the atomic, molecular or macromolecular levels, in the length scale of approximately $1-100$ nanometer range, to provide a fundamental understanding of phenomena and materials at the nanoscale and to create and use structures, devices and systems that have novel properties and functions because of their small and/or intermediate size. The novel and differentiating properties and functions are developed at a critical length scale of matter typically under $100 \mathrm{~nm}$. Nanotechnology research and development includes manipulation under control of the nanoscale structures and their integration into larger material components, systems and architectures. Within these larger scale assemblies, the control and construction of their structures and components remains at the nanometer scale. In some particular cases, the critical length scale for novel properties and phenomena may be under $1 \mathrm{~nm}$ (e.g., manipulation of atoms at $\sim 0.1 \mathrm{~nm}$ ) or be larger than $100 \mathrm{~nm}$ (e.g., nanoparticle reinforced polymers have the unique feature at $\sim 200-300 \mathrm{~nm}$ as a function of the local bridges or bonds between the nano particles and the polymer). ${ }^{8}$

Roco, Williams, and Alivisatos (1999), Roco (2001), and Roco and Brainbridge (2001) provide a thorough review of the present state of nano S\&T, the implementation of the NNI, and an introduction to thinking about the implications of nano S\&T for our economy and society. 
Nano S\&T has been a burgeoning area of science and engineering since at least 1990 as illustrated in Figure 1. This figure reports data which we obtained by searching on the topic "nano*" by year in the Science Citation Index Expanded (SCI-EXPANDED)--1975-May 30, 2003. The values for 1981 through 1989 (averaging one third article per thousand) reflect some of the substantial early scientific work as well as the background error in the search strategy. These values show no trend and none are significantly different from their mean. Since 1990 the growth in nano S\&T articles has been remarkable, and now exceeds 2 percent of all science and engineering articles. ${ }^{9}$

The patent data suggest a beginning date for nano S\&T some five years earlier than 1990 . Figure 2 presents data on patents granted by the end of 2000 containing the string "nano" in their title or description. The data is presented for two different dating conventions: by year the patent was granted and by the year the patent was applied for. The latter is more precise in terms of when the invention was actually made (typically about 3 months before the date of application), but suffers for the last five or six years from right truncation: Some patents applied for before 1996 were still pending at the end of 2000; as were many of those applied for in 1997-2000 and nearly all applied for in 2000. If we allow for a lag between application and grant dates (25 months was the difference in means in this sample), both series tell the same story. Patents applied for 1976-1985 and granted 1976-1986 had mean values of 37.4 and 33.3 patents per year and no observation within these periods differed from the respective means by as much as two standard deviations. Patent growth takes off in 1986: No number of patents applied for after 1985 (excluding the severely truncated 2000 observation) nor granted after 1986 were within two standard deviations of the cited means. 


\section{II.A. THE ENABLING INVENTIONS}

At this early date it is speculative to identify the key invention or inventions enabling rapid burgeoning of nanotechnology. Indeed, it may be that a confluence of breakthroughs will ultimately be seen as playing this role. ${ }^{10}$ At this point, we can say that one key enabling invention creating technological opportunity in nano S\&T is the development in the 1980s (with continuing improvements through the present) of scanning or proximal probe microscopy: "Ask a dozen surface scientists to identify key developments in instrumentation that are responsible for catapulting nanotechnology to the front lines of physical science research. Nearly all of them will point to the advent of scanning probe microscopy." (Jacoby 2001)

The scanning tunneling microscope (STM) was the first instrument to enable scientists to obtain atomic-scale images and ultimately to manipulate individual atoms on the surfaces of materials. It was invented in 1981 at IBM's Zurich Research Laboratory and reported by the inventors Gerd Karl Binnig and Heinrich Rohrer (1982 and 1983); they received the Nobel Prize in Physics in 1986 for their STM work. The STM works by moving a very fine pointer back and forth over a surface with each scan line displaced slightly from the next. A sensitive feedback mechanism maintains a constant distance relative to the surface so that a three dimensional representation is obtained. The procedure is called raster scanning in reference to the parallel lines which make up a television picture. The STM could be used only on conductive materials (metals) due to the electron tunneling method used to maintain the constant distance between pointer and surface.

The atomic force microscope (AFM) which was invented five years later by Binnig, Calvin Quate, and Christoph Gerber (1986) greatly broadened the range of materials which could be viewed at the atomic scale and enhanced the ability to manipulate individual atoms and 
molecules. Haberle, Horber, and Binnig (1991) report a modified AFM for use on living cells with which they observed the effects of antibody attachment and changes in salinity on living red blood cells. The invention of the AFM triggered an explosion in the microscopy of surfaces that continues through the present. ${ }^{11}$

We note that the inventions of methods or inventing by East and Jones, Cohen and Boyer, and Binnig, Rohrer, Quate, and Gerber are literally methodologies or instruments, not theoretical revolutions or paradigm shifts in response to nagging anomalies as argued by Kuhn (1962). The theoretical changes follow as the range of experimentation is broadened. Table 2 reports citation counts as of mid-July 2002 to the most-highly cited (250 or more citations) of the inventors' STM and AFM papers.

STMs and AFMs were initially only available to the few scientists with the resources and ability to construct one. Digital Instruments was the first of a number of firms to construct a commercially successful STM, shipping the first units in 1987. They introduced the first commercial AFM in 1989. The commercial availability of proximal probe devices facilitated if not enabled the rapid diffusion of nanoscale research. The usefulness of proximal probe microscopy was also greatly advanced in the late 1980s and 1990s as the rapid fall in the price of computing power has permitted multiple scans to be integrated into a three dimensional picture of a material that can be rotated and manipulated.

In conclusion, the history of breakthroughs in scanning probe microscopy as key enabling inventions for nano S\&T is consistent with the 1985-1990 initiation period which we detected by significant increases in the rate of patenting and publication. 


\section{II.B. CONCENTRATION OF NANOSCALE SCIENCE \& TECHNOLOGY}

As is frequently observed in other instances of metamorphic progress, nano S\&T has been highly concentrated in a few countries and a few regions in those countries. Figure 3 and Panel A of Table 1 illustrate that for the ISI's High Impact nano articles, 54 percent of the authors' addresses have been in the United States with another 29 percent divided among Australia, France, Germany, Japan, Switzerland, and the United Kingdom. ${ }^{12}$

Within the United States, nano S\&T publishing is similarly concentrated as shown by Figure 4 and Panel B of Table 1. The region including Los Angeles and Santa Barbara has the most authors' addresses on articles with at least one top-112 research university author. Silicon Valley and Boston follow close behind. When we look at things in terms of articles per million population, outstanding universities in relatively less urbanized regions make the areas around the University of Illinois at Champagne-Urbana and the North Carolina Research Triangle look outstanding not only within the U.S. but also for the 1991-1998 high-impact nano articles which are comparable to the last column of Panel A.

We expect that as the nanotechnology industry grows, we will also find that growth within the industry is concentrated in relatively few, very rapidly growing firms as is characteristic of metamorphic progress (Darby and Zucker 2003).

\section{II.C. COMPARISON OF NANO S\&T WITH BIOTECHNOLOGY}

Given the remarkable transformations due to biotechnology in treatment and diagnosis of disease and even the flowers we give, it might seem foolhardy to suggest that nano S\&T is following a similar trajectory. However, just as biotechnology covers all living things, nano S\&T covers the atomic and molecular level for all matter, organic or inorganic. The intersection of biotech and nano S\&T is certainly a large and important area, but even more is going on with 
respect to inorganic science and technology. The distribution of nano publishing is illustrated in Figure 5 which shows the percentage distribution for each semiannual volume of the Virtual Journal of Nanotechnology. ${ }^{13}$

Figure 6 illustrates the remarkable increase in publishing and patenting that occurred during the first twenty years of the biotechnology revolution and that is occurring now in nano S\&T.

For articles, nano S\&T is maintaining a growing lead over biotechnology articles. Recall that we so far identify nano articles as simply those that include the string "nano" in the ISI topic search (in the case of our aggregate data) or the article title (for our ISI flat files discussed below). We are working actively with our colleagues at the California NanoSystems Institute (CNSI) to improve the search methodology for identifying both articles and patents, aiming for defined subareas via new keywords. Defining biotech articles as any that report a genetic sequence (i.e., appear in GenBank) is also conceptually overly narrow, but it has been proven in practice a very useful measure in our work on biotech.

Nano S\&T patents were ahead of biotech patents early in the process because practically none were issued in biotech until the courts gave the go ahead in 1980 . Thirteen years into the biotech revolution (1986), biotech patenting took off as gene sequences were patented with little proof of their use and many variations on drug candidates were patented in an attempt to prevent quick competition from me-too drugs if one particular candidate were proved safe and effective.

Taken as a whole the scientific and patenting growth of nanotechnology is of the same order of magnitude as biotechnology at a similar state of development. 


\section{EMPIRICAL RESULTS ON ENTRY OF FIRMS INTO NANOTECHNOLOGY}

Zucker, Darby, and Brewer (1998), Darby and Zucker (2001), and Torero, Darby, and Zucker (2001) have shown that entry into high-tech industries undergoing metamorphic progress (U.S. and Japan biotech and U.S. semiconductors) can be explained well in terms of a poisson process: The probability of entry per unit time in a particular region depends upon the size of the academic science base - especially of active, star researchers - and the local economic climate as represented by the past level of venture capital funding, employment, and average wage per job (which serves as an indicator of the quality of the labor force). We attempt here to follow that strategy in explaining where and when firms enter nanotechnology.

In our previous work, we have stressed the importance of natural excludability as reinforcing formal intellectual property protection and ensuring that scientists with the requisite know-how were the scarce resources around which firms were formed or transformed. With the enabling technology now commercially accessible, it could be that natural excludability is less operative in nano S\&T. However, these instruments are being put to such novel uses and with sufficient tacit knowledge that the inventions are not likely to be licensed without the inventors' hands on involvement in making them work commercially. Where commercial opportunity is built on fast-advancing academic science it is generally more economical to establish commercial laboratories and even manufacturing facilities near the universities than to try to move the scientists and their network to an existing firm location.

This section is organized in four subsections. The first describes the data being used. The second presents the empirical results for entry into nanotechnology by all firms regardless of industry of application or science base. The third subsection presents a novel analysis relating 
entry of firms to the region's specific science base relevant to the applications pursued by those firms. The final subsection summarizes the results.

III.A. DATA

Following the approach of Zucker, Darby, and Brewer (1998), our variables are all defined for the years 1981-1999 for each of 172 distinct regions comprising every county of the United States. These regions correspond to the U.S. Bureau of Economic Analysis's Functional Economic Areas based on commuting and shopping patterns and described in Johnson (1995). Since the earliest evidence of increased nano S\&T activity occurred in 1985 and 1999 is the last year for which we have data for all the variables, our regressions are estimated for 1985-1999 with 1981-1984 values used to get good starting values for the various knowledge stock measures. ${ }^{14}$ These regions are the reporting units for the BEA's Regional Accounts Data. We downloaded employment and average wages for each region from http://www.bea.doc.gov/bea/regional/reis/ on July 15,2002 , but this data is available on the BEA's Regional Economic Information System and numerous other sources. Table 3 summarizes the definitions of all the variables used in the study. The sample statistics for the variables are given in Table 4.

Our major source of information for the regional nanoscale specific science base is the Institute of Scientific Information (2000a) database of all publications with at least one author affiliated to one of the top-112 research universities in the U.S. The ISI list of the top-112 research universities is included as Table Al. For this paper, we identified nano S\&T articles by searching for the string "nano" in their title. ${ }^{15}$ We used computer-based and hand matching to divide this base into those articles with at least one author affiliated with a firm and the 
remaining all-academic articles. We followed the same procedure with the Institute of Scientific Information (2000b) database of High-Impact (highly cited) papers.

We used the top-112 universities and high-impact academic papers separately to define measures of the science base by region and year. First we coded the specific region for each of the addresses given for authors on the paper. We then credited a fractional part of the paper to each region represented in the addresses equally. ${ }^{16}$ Thus for each region and year we have separate counts for academic top-112 articles and academic high-impact articles. These two counts are accumulated year by year with a $20 \%$ depreciation rate being applied to the knowledge stock of the previous year. We take the starting value in 1980 (before the invention of the STM) to be zero for all regions. We hypothesize that high-impact papers have a higher average quality level than the average top-112 paper and hence expect them to have a larger impact on firm birth.

We plan in future years to develop a database with extensive data on nanotech firms comparable to the one which we have developed for biotechnology. This task of integrating directory, archival, web-search, and survey data will take years and, meanwhile, there are no good alternative databases existing. Fortunately, for science-driven technologies essentially all significant firms encourage their scientists and engineers to publish their significant research results in academic journals - delaying publication only for the few months required to file for patent protection. As a result, we can use the rest of the ISI data - the top-112 and high-impact articles with firm authors - to identify firms active in nanotechnology and proxy for their date of entry.

Specifically we code each of these articles as to where the firm authors are located and count the firm as entering nanotechnology in a given region in the year of their first publication 
in a that region in the firm-article dataset. Thus, one firm may have multiple entry dates if it has employees authoring articles in different regions. This methodology identifies 202 firm entries in all, with 187 of them occurring 1991-1999. Over 68 percent of the 1991-1999 firm entries occurred in the 10 regions for which entries by year are illustrated in Figure 7 . Note the unevenness across regions of the upward trend in firm entry.

In subsection III.C below we use a modified definition of firm entry in which a firm is identified as entering a specific area of nanotechnology in a given region in the year of their first publication in a that region in a firm-article sub-dataset restricted to articles in a relevant sciencearea grouping. Thus - on this special definition - one firm may have multiple entry dates if it has employees authoring articles in different regions and/or has employees authoring articles in different major science-technology areas in the same region, but there will be at most one entry date per firm per region for any one of the major science-technology areas. The five major science-technology areas used are listed in Table A2 as defined in the Darby and Zucker (1999) monograph comparing California's science base with that in other hightech states. The distribution of firm entry across these fields is reported in Figure 8 for the same 10 regions as in Figure 7. Note that the proportional distribution of total entries by field is not even across regions, consistent with the hypothesis that differences in relative strengths of the science bases will cause uneven distribution of firm entry.

We have two non-article based measures of regional science base. The first is based on the NSF data on federal funding received by the top-100 universities in 2000 and tracking them back to 1981 (see Data Appendix for details). This funding is added up by region and year but can not be broken down further into the five major science-technology areas. The second measure is based on the 1993 National Research Council (NRC) study of U.S. research-doctorate 
programs (Goldberger, Maher, and Flattau 1995). We count the number of doctoral programs in science and engineering which are ranked in the top 10 (including all universities tied for $10^{\text {th }}$ place). ${ }^{17}$ We counted these highly ranked programs by region and used the same regional value for each year 1985-1999. We believe that given the current state of nanotechnology data it is acceptable to take the 1993 values as exogenous regional constants. For subsection III.C, we made these counts separately based only on rankings for doctoral programs in the same five broad science-technology categories listed in Table A2.

\section{III.B. EMPIRICAL RESULTS FOR ALL SCIENCE-TECHNOLOGY AREAS COMBINED}

Poisson regressions are appropriate as here when dealing with count variables with numerous zero values (Hausman, Hall, and Griliches 1984). The intuition of the model is that there are thousands of individuals and who might start a nanotech firm or subunit but the probability that any one of them will do so in a short period of time is very small. The time and region varying probability $\lambda$ is what is estimated as a function of the independent variables. All the regressions reported here were estimated using LIMDEP 7.0, with the Wooldridge (1991) regression-based correction for the variance-covariance matrix estimates. ${ }^{18}$

Table 5 reports the poisson regressions for firm entry. Column (a) and (b), respectively, report separate regressions for the science-and-engineering-base and regional economic variables with the venture capital variables excluded since it is problematic whether they should be viewed as reflecting the science base or the regional economic base. Column (c) reports the regression with all the variables in (a) and (b).

In column (a) we see that the high-impact articles dominate the (insignificant) top-112 university articles measure. This implies that - as with biotechnology - it is primarily the top science and scientists who spawn firms locally. Federal research funding is also significant and 
can be considered as either an input measure or, given the peer review involved, a supplementary quality measure. The NRC survey results are positive but not significant. ${ }^{19}$ Column (b) shows that average wage as a measure of work-force skill levels is positive and significant while employment as a measure of size is positive but not significant. In the combined regression (c) Federal research funding becomes insignificant and only the region's high-impact articles and skill level appear significant.

Measures of the frequency and size of recent venture capital deals in the region are added to these regressions in columns (d), (e), and (f). The venture capital variables generally are insignificant - although they enter inconsistently in regression (e). Comparing columns (d)-(f) with (a)-(c), we see that neither do the venture capital variables have much effect on the other significant variables in these regressions: The only exception being that regional size becomes significantly positive in regression (e) with the science-and-engineering base excluded.

The overall message of Table 5 then is that firms enter nanotechnology near where top scientists are making breakthrough discoveries and where skill levels in the work force are high. This does not exclude the possibility that federal research funding, highly-rated university doctoral publishing, and top-112-universities articles play a role - indeed each of these enter significantly positively in Poisson regressions (not reported here) which exclude the other 3 science-base measures. It does suggest that these variables play a role to the extent that they promote breakthrough discoveries as indicated by the high-impact article measure.

As we have emphasized above and in Darby and Zucker (2003), metamorphic progress is highly concentrated. In order to ensure that we are not capturing simply the concentration of entry in a relatively few regions, we report fixed-effects Poisson regressions in Table 6 analogous to those in Table 5, except that we estimate a different constant for each region, so 
that the remaining coefficients provide estimates based on deviations from average for each region by year. ${ }^{20}$ The results in Table 6 are remarkably similar to those in Table 5, with the main notable difference being that - with the means taken care of - we do see that fast growing regions (as measured by employment) do have significantly more entry than slow growing regions.

\section{III.C. EMPIRICAL RESULTS FOR SPECIFIC SCIENCE-TECHNOLOGY AREAS}

We would have liked to estimate separate poisson regressions for entry by firms into each of the five science-and-technology areas listed in Table A2. Unfortunately, as indicated by a close inspection of either Figure 8 or Table 4, most of these areas have so far had too little entry for these regressions to be estimable - while there are still 2580 observations, nearly all the lefthand variables are zeroes. Put another way, so far about 62 percent of entries (counted by region and science-and-technology areas) have occurred in the area of semiconductors, integrated circuits, and superconductors, and another 24 percent of these entries are accounted for by the biology, medicine, and chemistry area.

Tables 7 and 8 shows that entry of firms working in the broad area of semiconductors, integrated circuits, and superconductors, are explained by essentially the same processes as estimated in Tables 5 and 6 for all entries combined. This similarity is hardly surprising given the dominance of this science-and-technology area in the initial applications of nanotechnology. However, it is reassuring that the science base measured specifically in terms of this particular subset of articles and doctoral programs (but not research funding) gives the same answers as when the combined variables for all areas of science and engineering are used.

Tables 9 and 10 report the same set of regressions where the independent and dependent variables are defined in terms of the area of biology, medicine, and chemistry. The results are 
clearly fragile with relatively few entries through 1999 in bio-nanotechnologies. Federal research funding and average wage seem significant in Table 9 when the science base or regional economic variables are estimated separately, but only the average wages is significant in the full Poisson regression (f). Even that significance disappears in the fixed-effects Poisson regressions. There were no reportable results for the other three areas. We conclude that there has simply not been enough time as of yet to estimate separate equations by science-and-technology areas.

\section{III.D. SUMMARY OF THE EMPIRICAL EVIDENCE}

Based on the robust results for entry for all science-and-technology areas combined, we conclude that nanotechnology is following the same pattern as biotechnology: Firms are entering where and when academic scientists are making major scientific breakthroughs as well as where the quality of the labor force is high and, perhaps, growing rapidly. Other measures of the science base so far appear to be better viewed as increasing the probability of a breakthrough discovery rather than having a detectible independent result over and above that outcome. Venture capital and capitalists appear to flow to the technological opportunity rather than exerting an independent effect on where and when growth occurs, given that all the regions considered here are tied into the American financial system. 


\section{SUMMARY AND CONCLUSIONS}

We have argued that Grilichesian breakthroughs or inventions of methods of inventing occur when a scientific or engineering breakthrough creates appropriable technological opportunity across a broad range of distinct products. Most often these revolutionary inventions are in the less glamorous areas of methodology and instrumentation rather than high-theory paradigm shifts. We have seen that in Griliches's own case of hybrid seed corn the breakthrough was primarily on the appropriability side of the equation since other means of producing higher yield corn were available but could not yield a return to investing in their creation because of competition from saving part of the crop as seed.

Biotechnology combined formal protection on individual products (from 1980) with strong informal protection due to the high degree of natural excludability inherent in genetic engineering. This ensured an extended period of above-normal profits to those scientists who became involved in commercializing their discoveries. It still does so today to those at the frontiers of that rapidly expanding science, and provides incentives to the top scientists to move part of their labor to firms, a necessary part of the technology transfer process.

Nanotechnology opens a new range of possibilities to operate, control, and build at the atomic scale where unique processes and properties are available. The key enabling inventions classed as scanning probe microscopes became commercially available in a matter of five years or less after their invention; so there is relatively little natural excludability inherent in the instruments. However, the uses that these instruments are being put involves areas which are very imperfectly understood and other new methods of inventing may be at least as important as scanning probe microscopy. Thus the involvement of the inventing scientists may be very valuable in 
commercialization, and we note that many of the best nano scientists and engineers maintain their academic positions and research programs while co-founding and guiding new entrants or continuing relationships collaborating at the bench-science level with scientists from incumbent firms.

At this point in our empirical work, our conclusions have been supported through a variety of empirical measures and methods for biotechnology. In this paper we have presented evidence of a close coincidence in time and place of firms engaging in nanotechnology and the location of academic scientists and engineers making major breakthroughs. As our research on the commercialization of nanoscale science and technology continues we hope to provide further evidence on the major features of the two-way flows between academe and commerce and new insights based on more nearly real time data collection than is the norm for research on science, technology, and growth. 


\section{Data Appendix}

This appendix supplements the descriptions of the data set in the text and Tables 3 and 4 . All current dollar amounts are converted to 1996 dollars by deflating by the chain-type price index for personal consumption expenditures (PCECPI, U.S. Bureau of Economic Analysis 2002)

\section{Articles as Measure of Science Base}

Journal publishing is at the heart of the scientific enterprise and has been successfully used to measure the local science base in many past studies. We use two partially overlapping databases licensed from the Institute of Scientific Information (ISI, 2000a and 2000b). As described in the text and Table 3. Appendix Table A1 lists the 112 universities identified by ISI as top research institutions on the basis of receipt of federal research funding. ISI (2000a) lists all articles which have at least 1 author listing an address at one of these 112 institutions. The ISI (2000b) CD lists all articles, regardless of where authored, that meet the ISI threshold for most highly cited. We have divided these two data bases into those in which any firm is listed as an author's address and all others which we term purely academic. We assign these articles to regions using equal fractional weights for each listed address so that the total weights for each article equal 1 . The articles are dated by the year of their publication. We calculate knowledge stocks by region and year (see below) for all purely academic articles for both databases. ${ }^{21}$

We also disaggregate these articles into five broad science and engineering areas for which we can make meaningful comparison across a variety of data sources. Table A2 lists these areas and corresponding ISI journal fields. Table A.3 reports on the correspondence of these broad areas to the standard program names used in the NRC study of U.S. doctoral programs (Goldberger, Maher, and Flattau 1995, National Research Council 1995). This correspondence permits us to calculate area specific breakdowns of top-10 departments. 


\section{Knowledge Stocks}

Research and development is a multiyear process and inputs impact output measures over a number of years although the impact decreases over time. Therefore various inputs are measured as a knowledge stock:

$$
\mathrm{X}_{\mathrm{it}}=\mathrm{A}_{\mathrm{it}}+(1-\delta) \mathrm{X}_{\mathrm{i},-1}
$$

where $A_{i t}$ represents the current input for a given region $i$ and year $t$, and $\delta$ is the depreciation rate of knowledge. We assume a conventional value for $\delta$ of 0.2 ; see Griliches (1990).

\section{Research Funding}

Our data for university receipts of federal research funding is due to the U.S. National Science Foundation (NSF). We limit the series to the 100 institutions reported for 1993-2000 in NSF (2000, Table B-6). Our sources for funding for these institutions before 1993 are 19911992 NSF (1997, Table B-6), 1988-1990 NSF (1990, pages 18-19), and 1980-1987 NSF (1987, pages 15-16) with the following exceptions:

- 1981-1983 in NSF, (1981, 1982, 1983, Table C-16 for each year) for Mississippi State University, University of South Florida, Medical University of South Carolina, Thomas Jefferson University, Medical College of Wisconsin.

- 1984-1989 in NSF (1989, Table B-6) for Thomas Jefferson University.

- 1989 in NSF (1989, Table C-16) and 1990 in NSF (1997, Table B-6) for Medical University of South Carolina.

We coded which region each university was in, aggregated by region and year, and deflated by the PCECPI to obtain research funding in millions of 1996 dollars by region and year. The funding data could not be disaggregated into the five major science-and-technology areas. 


\section{Venture Capital}

Venture capital data was obtained by licensing the Venture Economics database, geocoding recipient firms by region and then aggregating number of deals and funds received by region and year. Since the venture capital funds are not specific to nanotechnology, we use the same methods as used to calculate knowledge stocks to calculate venture-capital deals and funding stocks as a general measure of past local availability of venture capital. These data indicate the general level of venture-capital activity in a region and we did not attempt to disaggregate these measures into the five major science-and-technology areas. 


\section{REFERENCES}

Binnig, Gerd Karl, Calvin F. Quate, and Christoph Gerber, “Atomic Force Microscope," Physical Review Letters, March 3, 1986, 56(9): 930-933.

Binnig, Gerd Karl, and Heinrich Rohrer, "Scanning Tunneling Microscopy," Helvetica Physica Acta, 1982, 55(6): 726-735.

Binnig, Gerd Karl, and Heinrich Rohrer, "Scanning Tunneling Microscopy," Surface Science, $1983, \underline{126}(1-3): 236-244$.

Binnig, Gerd Karl, and Heinrich Rohrer, "In touch with atoms," Reviews of Modern Physics, March 1999 Special Issue, 71(2): S324-S330.

Cohen, Stanley N., and Herbert W. Boyer, "Process for producing biologically functional molecular chimeras," United States Patent 4,237,224, December 2, 1980.

Cohen, Stanley, A. Chang, Herbert Boyer, and R. Helling, "Construction of Biologically Functional Bacterial Plasmids in vitro," Proceedings of the National Academy of Sciences, November 1973, 70(11): 3240-3244.

Darby, Michael R., and Lynne G. Zucker, California's Science Base: Size, Quality and Productivity, A Report to the California Council on Science and Technology, February 3, 1999, Sacramento, CA: California Council on Science and Technology, 1999.

Darby, Michael R., and Lynne G. Zucker, "Change or Die: The Adoption of Biotechnology in the Japanese and U.S. Pharmaceutical Industries," Comparative Studies of Technological Evolution, 2001, 7: 85-125.

Darby, Michael R., and Lynne G. Zucker, "Going Public When You Can in Biotechnology," National Bureau of Economic Research Working Paper No. 8954, May 2002. 
Darby, Michael R., and Lynne G. Zucker, "Growing by Leaps and Inches: Creative Destruction, Real Cost Reduction, and Inching Up," Economic Inquiry, 2003, 41: 1-19.

East, Edward M., and Donald F. Jones, Inbreeding and Outbreeding: Their Genetic and Sociological Significance, Philadelphia, PA: J. B. Lippincott Company, 1919.

Gilbert, Richard J., and David M.G. Newbery, "Preemptive Patenting and the Persistence of Monopoly," American Economic Review, June 1982, 72(3): 514-526.

Goldberger, Marvin L., Brendan A. Maher, and Pamela Ebert Flattau, eds., Research-Doctorate Programs in the United States: Continuity and Change, Washington, DC: National Academy Press, 1995.

Griliches, Zvi, "Hybrid Corn: An Exploration in the Economics of Technological Change," Ph.D. Dissertation, Department of Economics, University of Chicago, 1957. (1957a)

Griliches, Zvi, "Hybrid Corn: An Exploration in the Economics of Technological Change," Econometrica, October 1957, 25(4): 501-522. (1957b)

Griliches, Zvi, "Research Costs and Social Returns: Hybrid Corn and Related Innovations," Journal of Political Economy, Oct. 1958, 66(5): 419-431.

Griliches, Zvi, “Are Farmers Irrational?”, Journal of Political Economy, Feb. 1960, 68(1): 68-71. $(1960 \mathrm{a})$

Griliches, Zvi, "Hybrid Corn and the Economics of Innovation," Science, Jul. 29, 1960, 132(No. 3422): 275-280. (1960b)

Griliches, Zvi, “Hybrid Corn Revisited: A Reply,” Econometrica, Sept. 1980, 48(6): 1463-1465.

Griliches, Zvi, "Patent Statistics as Economic Indicators: A Survey," Journal of Economic Literature, December 1990, 28(4):1661-1707. 
Haberle, W., J. K. H. Horber, and Gerd Karl Binnig, "Force Microscopy on Living Cells," Journal of Vacuum Science \& Technology B, March-April 1991, Part 2, 9(2): 1210-1213. Hausman, Jerry, Bronwyn H. Hall, and Zvi Griliches. "Econometric Models for Count Data with an Application to the Patents-R\&D Relationship." Econometrica, July 1984, 909-938.

Institute of Scientific Information (ISI), U.S. University Science Indicators, machine-readable database on CD-ROM. Institute of Scientific Information, Philadelphia, PA, 2000. (2000a)

Institute of Scientific Information (ISI), High Impact Papers, 81-98, in 22 Broad Fields, machine-readable database on CD-ROM. Institute of Scientific Information, Philadelphia, PA, 2000. (2000b)

Jacoby, Mitch, "New tools for tiny jobs," Chemical and Engineering News, Oct. 16, 2000, 78(42): $33-35$.

Jensen, Richard A., and Marie C. Thursby, "Proofs and Prototypes for Sale: The Tale of University Licensing," American Economic Review, March 2001, 91(1): 240-259.

Johnson, Kenneth P., "Redefinition of the BEA Economic Areas," Survey of Current Business, February 1995, 75(2): 75-81.

Kannenberg, L. W., "Corn Hybrids: Corn Breeding in the 20th Century," Ontario Corn Producer on-line edition, December 1999, http://www.ontariocorn.org/dec99feat.html.

Klevorick, Alvin K., Richard C. Levin, Richard R. Nelson, and Sidney G. Winter, "On the Sources and Significance of Interindustry Differences in Technological Opportunities,” Research Policy, March 1995, 24(2): 185-205.

Kuhn, Thomas S., The Structure of Scientific Revolutions, Chicago: University of Chicago Press, 1962. 
Lewontin. Richard C., Biology As Ideology: The Doctrine of DNA, New York, NY: Harper Perennial, 1993.

Mowery, David C., and Arvids A. Ziedonis, “The Geographic Reach of Market and Non-Market Channels of Technology Transfer: Comparing Citations and Licenses of University Patents," National Bureau of Economic Research Working Paper No. 8568, October 2001.

National Research Council, Research-Doctorate Programs in the United States: Data Set, machine-readable database, Washington, DC: National Academy Press, 1995.

Roco, Mihail C., "From Vision to Implementation of the U.S. National Nanotechnology Initiative," Journal of Nanoparticle Research, Feb. 2001, 3(1): 5-11. http://kapis.wkap.nl/sample.pdf?324433

Roco, Mihail C., and William Sims Bainbridge, eds., Societal Implications of Nanoscience and Nanotechnology, Boston, MA: Kluwer Academic Publishers, 2001. http://www.wtec.org/loyola/nano/societalimpact/ anosi.pdf

Roco, Mihail C., R. Stanley Williams, and Paul Alivisatos, eds, Nanotechnology Research Directions: IWGN Workshop Report -Vision for Nanotechnology in the Next Decade, Boston, $\quad$ MA: Kluwer Academic Publishers, 1999. http://www.wtec.org/loyola/nano/IWGN.Research.Directions/

Schmookler, Jacob, Invention and Economic Growth, Cambridge, MA: Harvard University Press, 1966.

Schmookler, Jacob, Patents, Invention, and Economic Change: Data and Selected Essays, Zvi Griliches and Leonid Hurwicz, eds., Cambridge, MA: Harvard University Press, 1972. 
Torero, Máximo, Michael R. Darby, and Lynne G. Zucker, "The Importance of Intellectual Human Capital in the Birth of the Semiconductor Industry," UCLA Working Paper, January 2001.

U.S. Bureau of the Census, Statistical Abstract of the United States: 1991, $111^{\text {th }}$ ed., Washington: U.S. Government Printing Office, 1991.

U.S. Bureau of Economic Analysis, "Table 7.4. Chain-Type Quantity and Price Indexes for Personal Consumption Expenditures by Major Type of Product," National Income and Product Accounts Tables, http://www.bea.doc.gov/bea/dn/nipaweb/, rev. June 27, 2002

U.S. National Science Foundation, Federal support to universities, colleges, and selected nonprofit institutions. Fiscal Year 1981, Washington, DC: U.S. Government Printing Office, 1981.

U.S. National Science Foundation, Federal support to universities, colleges, and selected nonprofit institutions. Fiscal Year 1982, Washington, DC: U.S. Government Printing Office, 1982.

U.S. National Science Foundation, Federal support to universities, colleges, and selected nonprofit institutions. Fiscal Year 1983, Washington, DC: U.S. Government Printing Office, 1983.

U.S. National Science Foundation, Federal support to universities, colleges, and selected nonprofit institutions. Fiscal Year 1987, Washington, DC: U.S. Government Printing Office, 1987.

U.S. National Science Foundation, Federal support to universities, colleges, and selected nonprofit institutions. Fiscal Year 1989, Washington, DC: U.S. Government Printing Office, 1989. 
U.S. National Science Foundation, Federal support to universities, colleges, and selected nonprofit institutions. Fiscal Year 1990, Washington, DC: U.S. Government Printing Office, 1990.

U.S. National Science Foundation, Federal science and engineering support to universities, colleges, and nonprofit institutions. Fiscal Year 1997, Arlington, VA : Division of Science Resources Studies, Directorate for Social, Behavioral and Economic Sciences, National Science Foundation, 1997; http://www.nsf.gov/sbe/srs/nsf99331/tables.htm.

U.S. National Science Foundation, Federal science and engineering support to universities, colleges, and nonprofit institutions. Fiscal Year 2000, Arlington, VA: Division of Science Resources Studies, Directorate for Social, Behavioral and Economic Sciences, National Science Foundation, 2000; http://www.nsf.gov/sbe/srs/nsf02319/sectb.htm.

Vettiger P, M. Despont, U. Drechsler, U. Durig, W. Haberle, M. I. Lutwyche, H. E. Rothuizen, R. Stutz, R. Widmer, and G. K. Binnig, “The 'Millipede' - More than one thousand tips for future AFM data storage," IBM Journal of Research and Development, May 2000, 44(3): 323-340.

Wooldridge, Jeffrey M., "On the Application of Robust, Regression-Based Diagnostics to Models of Conditional Means and Conditional Variances," Journal of Econometrics, January 1991, 47: $5-46$.

Zucker, Lynne G., and Michael R. Darby, "Virtuous Circles of Productivity: Star Bioscientists and the Institutional Transformation of Industry," National Bureau of Economic Research Working Paper No. 5342, November 1995. 
Zucker, Lynne G., and Michael R. Darby, "Star Scientists and Institutional Transformation: Patterns of Invention and Innovation in the Formation of the Biotechnology Industry,” Proceedings of the National Academy of Sciences, November 12, 1996, 93(23): 12,70912,716 .

Zucker, Lynne G., and Michael R. Darby, "Present at the Biotechnological Revolution: Transformation of Technical Identity for a Large Incumbent Pharmaceutical Firm," Research Policy, December 1997, 26(4\&5): 429-446.

Zucker, Lynne G., Michael R. Darby, and Jeff Armstrong, "Commercializing Knowledge: University Science, Knowledge Capture, and Firm Performance in Biotechnology," Management Science, January 2002, 48(1): 138-153.

Zucker, Lynne G., Michael R. Darby, and Marilynn B. Brewer, "Intellectual Human Capital and the Birth of U.S. Biotechnology Enterprises," American Economic Review, March 1998, 88(1): 290-306.

Zucker, Lynne G., Michael R. Darby, Marilynn B. Brewer, and Yusheng Peng, "Collaboration Structure and Information Dilemmas in Biotechnology: Organizational Boundaries as Trust Production," in Roderick M. Kramer and Tom R. Tyler, eds., Trust in Organizations, Thousand Oaks, CA: Sage, 1996.

Zucker, Lynne G., Michael R. Darby, and Máximo Torero, "Labor Mobility from Academe to Commerce," Journal of Labor Economics, July 2002, 20(3): 629-660. 


\section{FOOTNOTES}

${ }^{1}$ Biotechnology covers a large field, and other basic discoveries like polymer chain reaction (PCR) and monoclonal antibodies (MABS) both were instrumental in the success of genetic engineering and led to independent trajectories of invention and innovation.

${ }^{2}$ Nano- is a prefix meaning one billionth (i.e., $\left.1 / 1,000,000,000\right)$ so nanoscale refers to working at sizes measured in the range of one to hundred billionths of a meter. A human hair is on the order of 50,000 nanometers in diameter.

${ }^{3}$ Many important inventions arise in universities and national labs in the course of research supported, in whole or part, by the federal and/or state governments. For those inventions discovery is not at issue and only the licensing fees and other costs of transferring the knowledge to the firm apply.

${ }^{4}$ Sun Microsystems charges computer manufacturers only a nominal fee to install the Java ${ }^{\mathrm{TM}}$ Virtual Machine software on their machine and any significant profits result from Sun's selling complementary hardware with the aura of controlling the past and future development of Java ${ }^{\mathrm{TM}}$.

${ }^{5}$ Interestingly, East and Jones did not attempt to patent their invention as UCSF and Stanford later did Cohen and Boyer's discovery, but instead confronted Aiken's theorem: "Don't worry about people stealing your ideas. If your ideas are any good, you'll have to ram them down people's throats." (Howard H. Aiken invented the first programmable mechanical computer the Mark I completed in 1943 - and shares parental credit for the electronic computer, itself a pretty good invention of a method of inventing.) George H. Shull working at the Carnegie Institution's Cold Spring Harbor Laboratory had also observed the increased yield with doublecross hybrids in 1910-1911 but did not publish his results nor appreciate their importance.

${ }^{6}$ The case of hybrid seed corn deserves a thorough study by another Griliches to sort out why the 
proof of concept for appropriable double-cross hybrids appears to have been completed by 1920 , the first firm was founded in 1926, and as late as 1934 a trivial percentage - considerably under 5 percent on all accounts - of corn acreage was planted with hybrid seed corn. Ten years later in 1944, 59 percent of all U.S. acreage, including 90 percent of the Corn Belt, was planted using hybrid seed (Kannenberg 1999). One possible clue is that Henry A. Wallace became Secretary of Agriculture in 1933 and Vice President in 1940.

${ }^{7}$ The invention is reported in Cohen, Chang, Boyer, and Helling (1973) and patented in Cohen and Boyer (1980). See footnote 1 above on other inventions enabling biotechnology.

${ }^{8}$ Subcommittee on Nanoscale Science, Engineering and Technology (NSET), Committee on Technology, National Science and Technology Council, February 2000, as posted at http://nano.gov/omb nifty $50 . h t m$.

${ }^{9}$ Beginning in 1990 the counts of nano articles per $1000 \mathrm{~S} \& \mathrm{E}$ articles was significantly greater than the 1981-1989 mean and increasing every year.

${ }^{10}$ Besides scanning or proximal probe microscopy, candidates for enabling breakthroughs include quantum dots, carbon nanotubes, and the phenomenal drop in the cost of computing.

${ }^{11}$ Remarkably, Vettiger, ..., and Binnig (2000) report on the "millipede" which uses an array of over 1024 tiny AFMs with read/write capability to achieve high speed data storage and retrieval at a density of 100-200 gigabytes per square inch $\left(\mathrm{Gb} / \mathrm{in}^{2}\right)$. "The very large scale integration (VLSI) of micro/nanomechanical devices (cantilevers/tips) on a single chip leads to the largest and densest 2D array of $32 \times 32$ (1024) AFM cantilevers with integrated write/read storage functionality ever built. Time-multiplexed electronics control the write/read storage cycles for parallel operation of the Millipede array chip. Initial areal densities of $100-200 \mathrm{~Gb} / \mathrm{in}^{2}$ have been achieved with the $32 \times 32$ array chip, which has potential for further improvements. In addition 
to data storage in polymers or other media, and not excluding magnetics, we envision areas in nanoscale science and technology such as lithography, high-speed/large-scale imaging, molecular and atomic manipulation, and many others in which Millipede may open up new perspectives and opportunities.”

${ }^{12}$ On a per capita basis (Table 1, Panel A), the United States loses its lead to Switzerland. Since Switzerland is a scientific powerhouse and the origin of the enabling technology (by employees of a firm headquartered in America), it is natural that they are world leaders.

${ }^{13}$ The Virtual Journal of Nanoscale Science \& Technology is an internet publication of the American Institute of Physics and the American Physical Society. It provides links to nano S\&T articles published in regular refereed journals. Since it started in January 2000, it has served as a central resource for the nano S\&T community, the editorial board has identified and classified 7,466 articles.

${ }^{14}$ Thus, N, the number of observations equals 15 years (1985-1999) times 172 regions which is 2,580. In our work on biotechnology we used the BEA definition of 183 functional economic areas operative at the time the industry was forming. For nanotechnology, we have switched to the current definition of 172 economic areas since it more nearly corresponds to regions during the formation of this industry.

${ }^{15}$ We are developing what we hope will prove to be an improved search methodology with the goal of increasing the completeness of coverage without an unreasonable rate of false positives. The resulting list of articles will be available for future work by other researchers and ourselves. ${ }^{16}$ ISI does not associate each author with a specific address, so we allocated credit equally among the addresses listed. If there were 3 addresses on a paper and 2 were in region 10 and 1 in region 20 , then region 10 is credited with $2 / 3$ of an article and region 20 with $1 / 3$ of an article. 
Papers with foreign authors will add up to less than 1 when summed across the 173 U.S. regions.

${ }^{17}$ We also experimented with including a count of all other doctoral programs in science and engineering which are ranked in the top 30 (including all universities tied for $30^{\text {th }}$ place). This was uniformly insignificant when included with other measures of the science base so we dropped it to simplify the discussion.

18 The significance of key variables in these regressions is generally not sensitive to the Wooldridge correction, but to achieve an estimate of the variance-covariance matrix that is not restricted by first-moment parameter estimates, we apply the Woodridge correction. An alternative would be to implement a binomial specification, but as explained in Wooldridge (1991), this procedure may bias both first and second moment estimates, whereas the Poisson process potentially biases only the second moment parameters

${ }^{19}$ The insignificance of top-112 university articles and top-10 doctoral programs occurs when all four, correlated measures of science base are in the same equation. Each variable is very significantly positive in a one-variable regression.

${ }^{20} \mathrm{We}$ must drop the top-10 doctoral program from the estimates because the values are constant for a given region. Conventionally, the 172 individual constants for each region are unreported. We cannot compute Wooldridge corrections for the standard errors but individual regional constants should obviate any problem arising from excess zeroes.

${ }^{21}$ We also experimented with knowledge stocks based on purely academic articles with at least one top-112 university author which were published in the top 5 percent and separately the second 5 percent of ISI journals in terms of average citations per article within each of the 5 broad S\&E fields in Table A2. These measures were dropped since they were always insignificant when the top-112 university articles or high-impact articles measures were in the regression. 


\section{Table 1}

Concentration of Nanoscale Science and Engineering Articles by Nations and in the U.S.

\begin{tabular}{|c|c|c|c|}
\hline \multicolumn{4}{|c|}{ Panel A -- National Data } \\
\hline \multirow[t]{2}{*}{ Nations } & \multicolumn{3}{|c|}{ Nano S\&T Articles } \\
\hline & $\begin{array}{c}1990-98 \\
\text { High Impact }^{\mathrm{a}} \\
\% \text { of World Total }\end{array}$ & $\begin{array}{c}1990-98 \\
\text { High Impact }^{\mathrm{a}} \\
\text { per million }^{\mathrm{c}}\end{array}$ & $\begin{array}{c}\text { 1991-98 } \\
\text { High Impact }^{\mathrm{a}} \\
\text { per million }^{\mathrm{c}}\end{array}$ \\
\hline Australia & $4.1 \%$ & 0.77 & 0.71 \\
\hline France & $4.0 \%$ & 0.22 & 0.22 \\
\hline Germany & $6.9 \%$ & 0.27 & 0.26 \\
\hline Japan & $5.5 \%$ & 0.14 & 0.14 \\
\hline Switzerland & $4.5 \%$ & 2.08 & 2.08 \\
\hline United Kingdom & $3.8 \%$ & 0.21 & 0.21 \\
\hline United States & $53.9 \%$ & 0.68 & 0.63 \\
\hline Subtotal & $82.7 \%$ & 0.44 & 0.42 \\
\hline Rest of World & $17.3 \%$ & 0.01 & 0.01 \\
\hline World Total & $100.0 \%$ & 0.06 & 0.06 \\
\hline
\end{tabular}

Regions Nano S\&T Articles

\begin{tabular}{ccc}
\hline 1990-99 & $1990-99$ & $1991-98$ \\
Top-112 Univs. $^{\text {a }}$ & Top-112 Univs. $^{b}$ & High Impact $^{a}$ \\
\% of U.S. Total & per million $^{c}$ & per million $^{c}$
\end{tabular}

Atlanta
Boston
Champagne-Urbana
Chicago
Hartford-New Haven
Los Angeles/Santa Barbara
New York
Philadelphia
Raleigh-Durham
San Francisco Bay
Subtotal
Rest of the United States
United States Total

\begin{tabular}{ccc}
$3.5 \%$ & 25.79 & 2.32 \\
$8.7 \%$ & 39.24 & 2.30 \\
$4.5 \%$ & 312.76 & 10.20 \\
$4.5 \%$ & 14.23 & 1.10 \\
$3.4 \%$ & 27.25 & 0.30 \\
$10.0 \%$ & 18.15 & 0.74 \\
$5.3 \%$ & 7.94 & 0.70 \\
$4.6 \%$ & 16.61 & 1.10 \\
$3.8 \%$ & 94.67 & 8.19 \\
$9.6 \%$ & 38.63 & 2.68 \\
\hline $57.8 \%$ & 22.24 & 1.36 \\
$42.2 \%$ & 5.51 & 0.34 \\
\hline $100.0 \%$ & 10.29 & 0.63
\end{tabular}

Notes: a. High Impact Papers, 81-98, Institute of Scientific Information (2000b).

b. U.S. University Science Indicators, Institute of Scientific Information (2000a).

c. Population estimates for 1990 taken from U.S. Bureau of the Census (1991, no. 1434) 
Table 2

Highly Cited Articles (over 250 Citations) by the Inventors of The Scanning Tunneling Microscope (STM) and the Atomic Force Microscope (AFM)

\section{Cites Publication}

546 Binnig, Gerd Karl, Heinrich Rohrer, Christoph Gerber, and E. Weibel, "Tunneling through a Controllable Vacuum Gap," Applied Physics Letters, 1982, 40(2): 178-180.

739 Binnig, Gerd Karl, and Heinrich Rohrer, "Scanning Tunneling Microscopy," Helvetica Physica Acta, 1982, 55(6): 726-735.

308 Binnig, Gerd Karl, and Heinrich Rohrer, "Scanning Tunneling Microscopy," Surface Science, 1983, 126(1-3): 236-244.

947 Binnig, Gerd Karl, Heinrich Rohrer, Christoph Gerber, and E. Weibel, "7X7 Reconstruction on Si(111) Resolved in Real Space," Physical Review Letters, 1983, 50(2): 120-123.

3,436 Binnig, Gerd Karl, Calvin F. Quate, and Christoph Gerber, "Atomic Force Microscope," Physical Review Letters, March 3, 1986, 56(9): 930-933.

409 Binnig, Gerd Karl, and Heinrich Rohrer, "Scanning Tunneling Microscopy," IBM Journal of Research and Development, July 1986, 30(4): 355-369.

258 Binnig, Gerd Karl, Christoph Gerber, E. Stoll, T. R. Albrecht, and Calvin F. Quate, "Atomic Resolution with Atomic Force Microscope," Europhysics Letters, June 15, 1987, $\underline{3}(12)$ : 1281-1286.

296 ainnig, Gerd Karl, and Heinrich Rohrer, "Scanning Tunneling Microscopy - From Birth to Adolescence," Reviews of Modern Physics, July 1987, 59(3): 615-625.

Source: ISI Science Citation Index Expanded (SCI-EXPANDED)--1975-present (Updated July 15, 2002) Note: a. 296 is the total for three versions of this article published nearly simultaneously. 


\section{Table 3 \\ Definitions of the Variables}

For those variables marked with an asterisk $(*)$, there are alternative series calculated depending on whether the variable refers to all science-and-technology areas combined or to one of the five specific science-and-technology fields as defined in Tables A2 and A3.

Article stocks* Knowledge stock in a given year and region as measured by counts of nano articles of a specified type excluding articles with firm authors (see immediately below) cumulated from 1981 according to $\mathrm{X}_{\mathrm{it}}=\mathrm{A}_{\mathrm{it}}+$ $(1-\delta) \mathrm{X}_{\mathrm{i}, \mathrm{t}-1}$ where $\mathrm{X}_{\mathrm{i}, 1980}=0, \mathrm{~A}_{\mathrm{it}}$ is the number of articles of the specified type in region $i$ in year $t$ and $\delta$ is the depreciation rate of knowledge. We assume a conventional value for $\delta$ of 0.2 ; see Griliches (1990).

Articles-high-impact* Knowledge stock where the input article series $\mathrm{A}_{\mathrm{it}}$ is a count of articles with no firm authors in the ISI High-Impact database.

Articles-top-112* Knowledge stock where the input article series $\mathrm{A}_{\mathrm{it}}$ is drawn from articles with no firm authors and in the ISI High-Impact database.

Average wage BEA series "Average Wage per Job" $1996 \$ 1000 \mathrm{~s}$ a by year and region.

Doctoral programs in top $10^{*}$ This is a count of science and engineering programs ranked among the top 10 in the U.S. in the 1993 National Research Council (NRC) study

Employment

Entry* BEA series "Total Full-time and Part-time Employment" in millions of jobs by year and region

Entry to date*

Number of firms entering nano S\&T in a given year and region. For this paper, we define a firm's entry as the first year that an author affiliated with the firm publishes a nano article in the given region.

Region

Cumulative entry of firms in a given region from 1981 up through given year.

Research funding

One of the 172 functional economic areas described in Johnson (1995).

(a)

Venture capital

funding

Research funding in millions of 1996 dollars $^{\mathrm{a}}$ is the sum for the region and year of federal funding going to the top-100 universities as reported by the National Science Foundation.

Venture capital deals Stock of venture capital deals reported in the Venture Economics database ( $20 \%$ depreciation)

Note: a. All current dollar amounts are converted to 1996 dollars by deflating by the chain-type price index for personal consumption expenditures (U.S. Bureau of Economic Analysis 2002) 
Table 4

Sample Statistics of the Variables, 1985-1999

Variables

Units

Variables invariant with science \& technology fields:

Research funding

Research funding stock

Venture capital funding

Venture capital funding stock

Venture capital deals

Venture capital deals stock

Employment

Average wage millions of 1996 dollars

millions of 1996 dollars

billions of 1996 dollars

billions of 1996 dollars

count of deals

count of deals

millions of jobs

thousands of 1996 dollars
Mean

0.05

0.22

0.09

0.28

14.91

56.10

0.83

23.73

Std. Dev.

Minimum Maximum

Variables for all science \& technology fields combined:

Entry
Entry to date
Articles-top-112 flow
Articles-top-112 stock
Articles-high-impact flow
Aritcles-high-impact stock
Doctoral Programs in top 10

count of firms

count of firms

0.08

0.37

0.45

0.14

0.58

0.49

1.11

64.19

223.21

1.48

3.27

count of articles

1.32

2.09

4.55

count of articles

3.66

12.81

count of articles

0.06

0.31

count of articles

0.20

1.38

0.86

count of programs

5.22

0.02

0.11

0.17

0.59

0.33

1.31

0.95

3.30

0.01

0.07

0.02

0.14

0.60

2.38

count of programs

Aritcles-high-impact stock

Doctoral Programs in top 10

count of articles

Variables for Integrated Circuit/Semiconductors/Superconductors:

Entry

Entry to date

Articles-top-112 flow

Articles-top-112 stock

Articles-high-impact flow

Aritcles-high-impact stock

Doctoral Programs in top 10

(concluded on following page) count of firms $\quad 0.06$

count of firms

0.26

0.79

2.18

0.04

0.12

0.24

count of articles

count of programs

count of articles
0.35

1.66

2.82

7.90

0.21

0.56

1.06
1.12

5.00

16.87

28.69

1547.00

4363.35

14.16

38.39

16.60

7

41

53.33

156.40

4.38

9.36

46

3

10

21.82

46.60

1.00

2.13

21

0.24

$\begin{array}{ll}0.06 & 0.35 \\ 0.26 & 1.66 \\ 0.79 & 2.82 \\ 2.18 & 7.90 \\ 0.04 & 0.21 \\ 0.12 & 0.56 \\ 0.24 & 1.06\end{array}$

6 
Table 4 (concluded)

Variables

Units

Mean

Std. Dev. Minimum Maximum

Variables for Computer/Information processing/Multimedia:

Entry

Entry to date

count of firms

count of firms

0.00

0.00

0.03

0.00

0.06

count of articles

0.01

Articles-top-112 stock

count of articles

0.06

0.10

count of articles

0

count of articles

0

Aritcles-high-impact stock

count of programs

0.12

0

0

Doctoral Programs in top 10

$0.12-0.57$

0.00

0.07

0.01

0.11

$0.03 \quad 0.22$

0.22
0.43

0.06

0

count of articles

0

0

Aritcles-high-impact stock

count of articles

0.18

0

count of programs

$\begin{array}{ll}0.18 & 0.64\end{array}$

0.64

0.01

0.09

0.27

0.37

0.07

0.92

0.22

0.15

0.02

0.36

0.06

0.36

count of programs

0.23

0.97

2

2

4.50

9.06

0

0

5

Doctoral Programs in top 10

Note: The number of observations $(\mathrm{N})$ is 15 years $\mathrm{x} 172$ regions $=2,580$. 


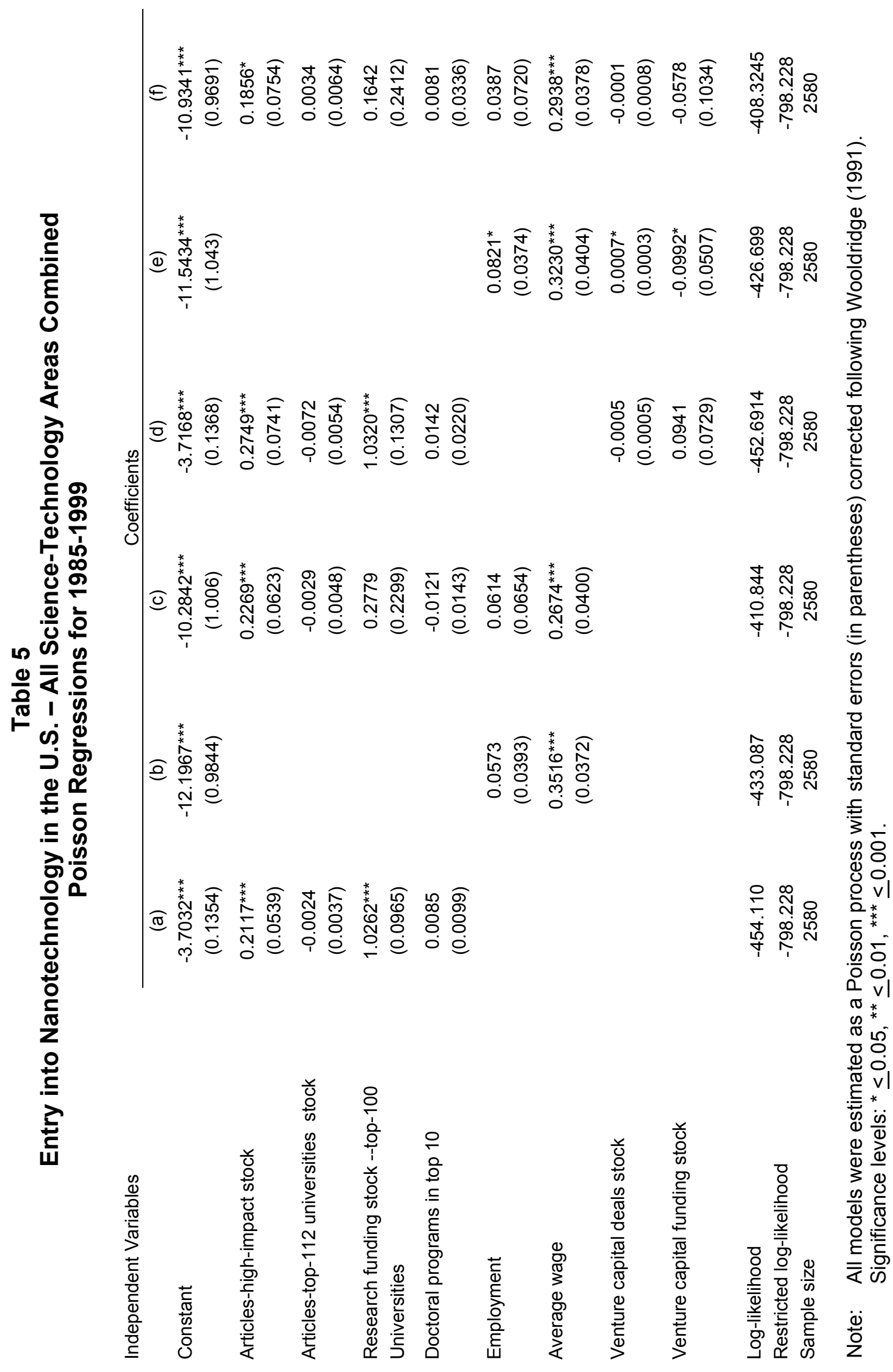




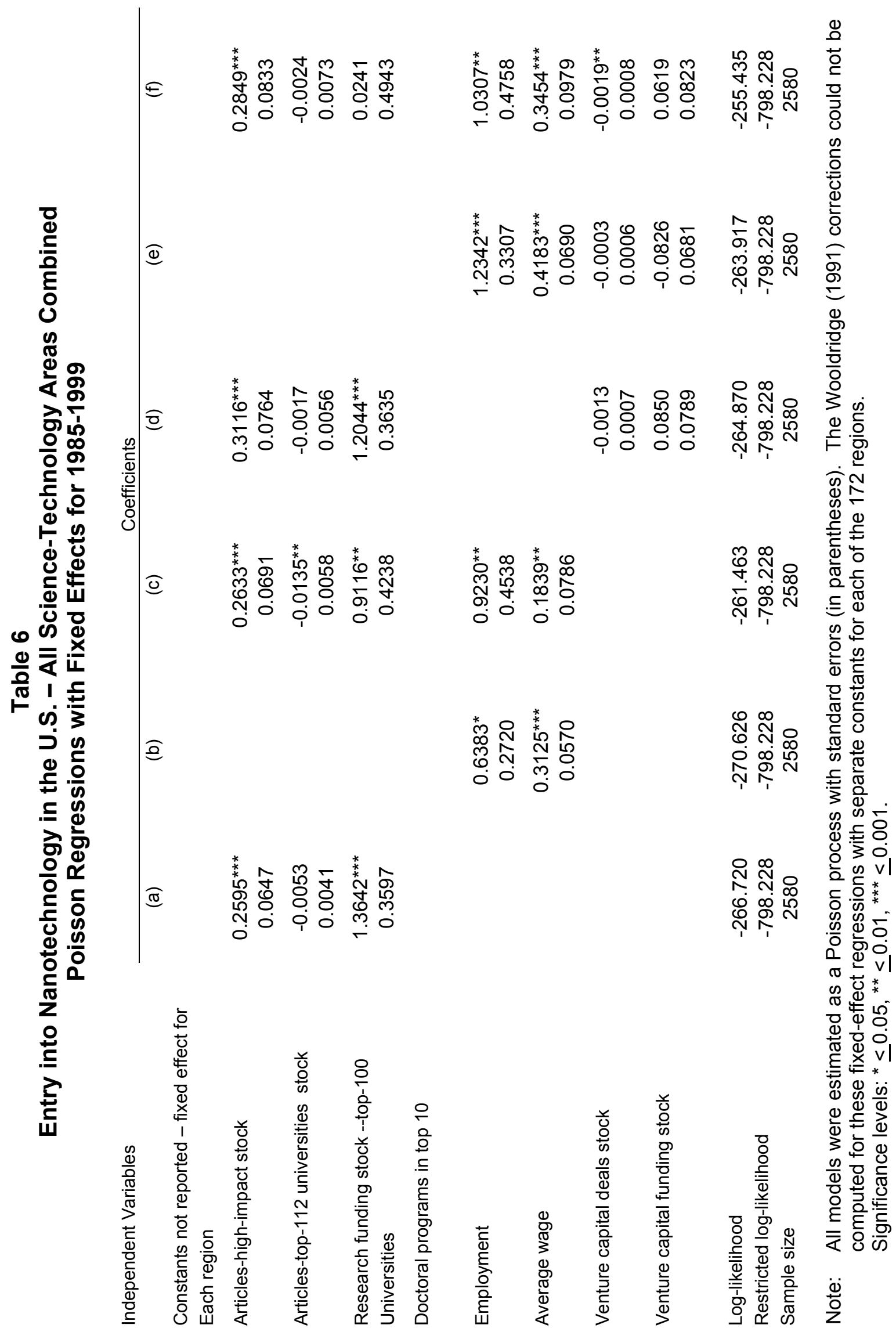




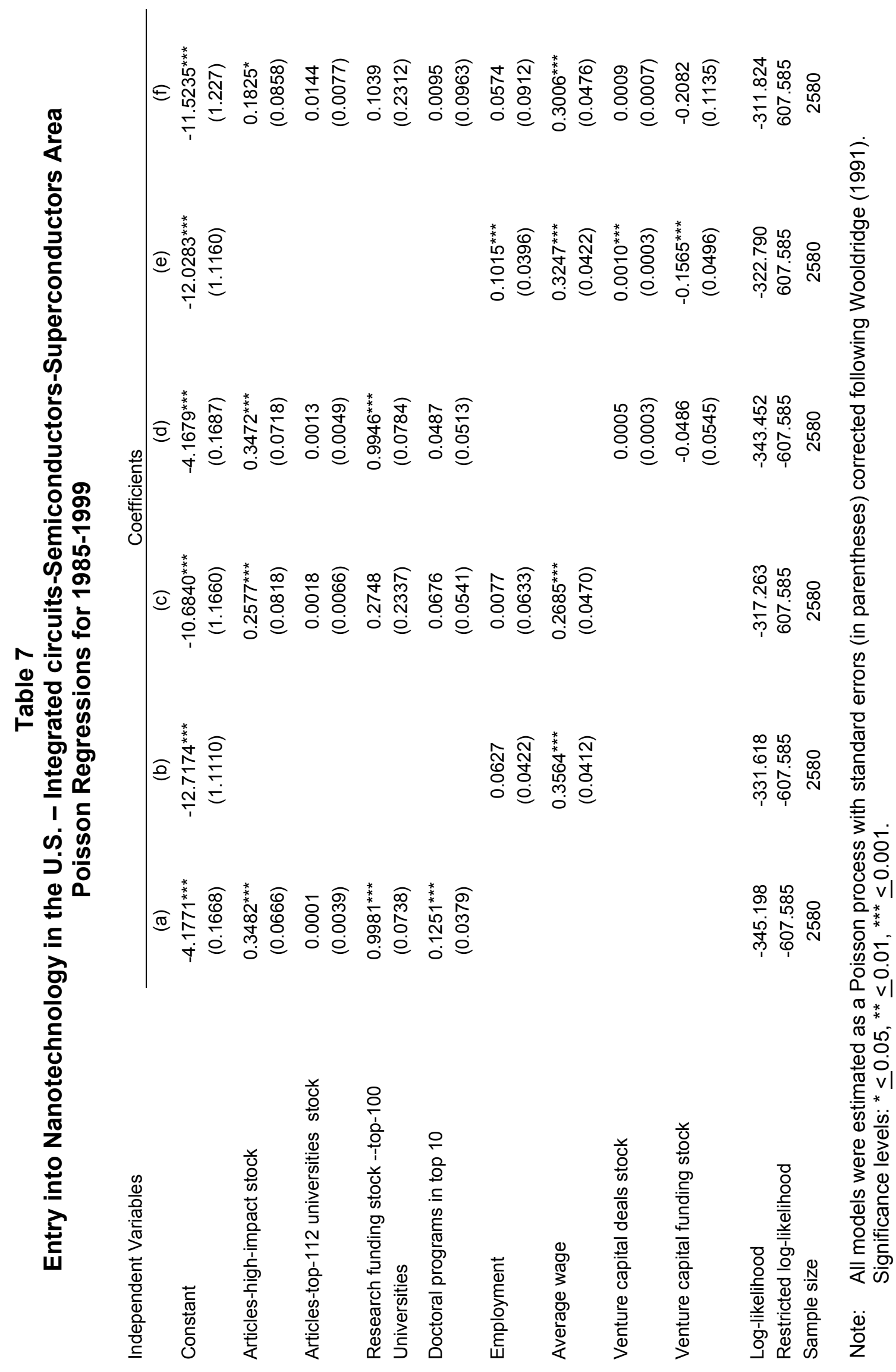




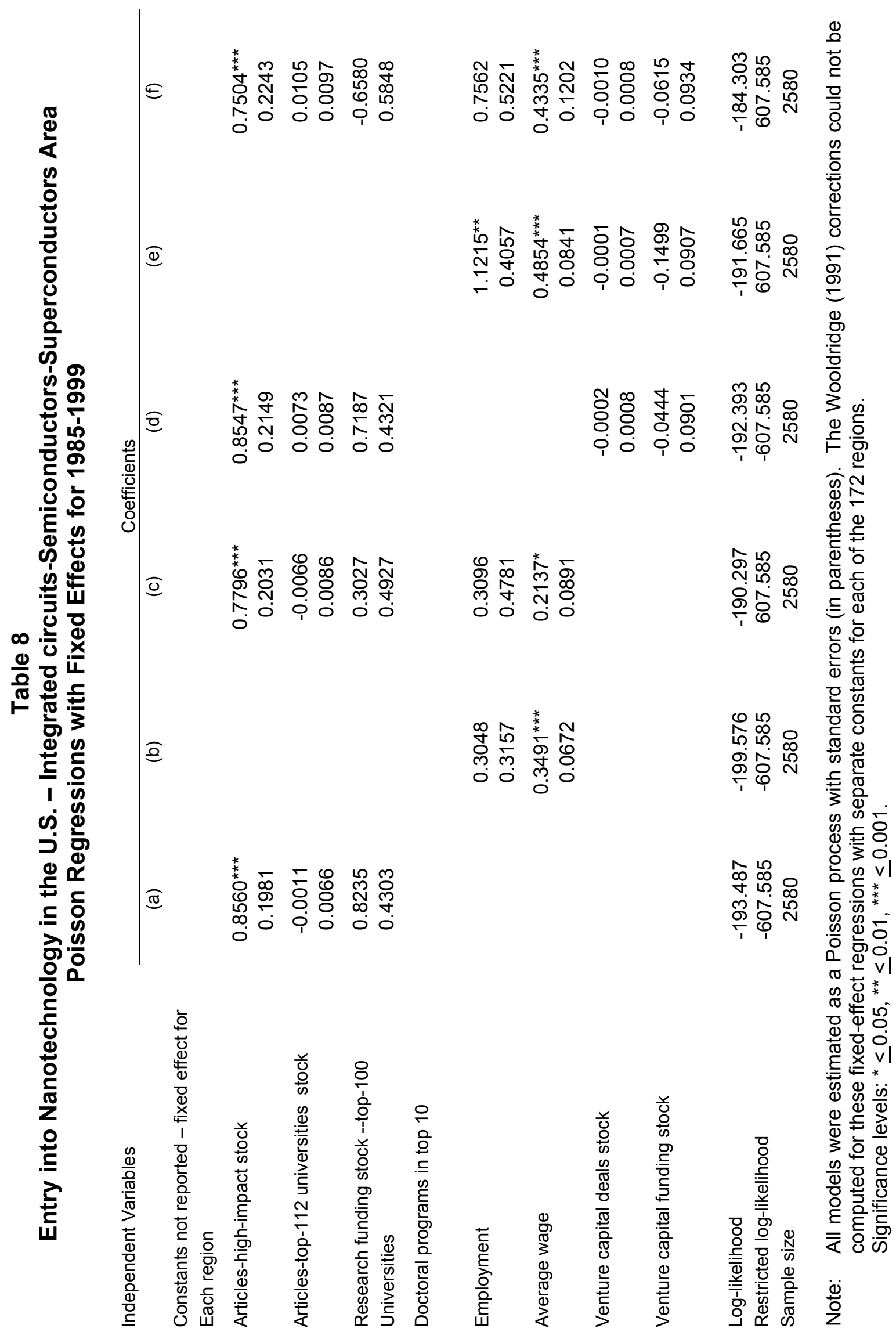




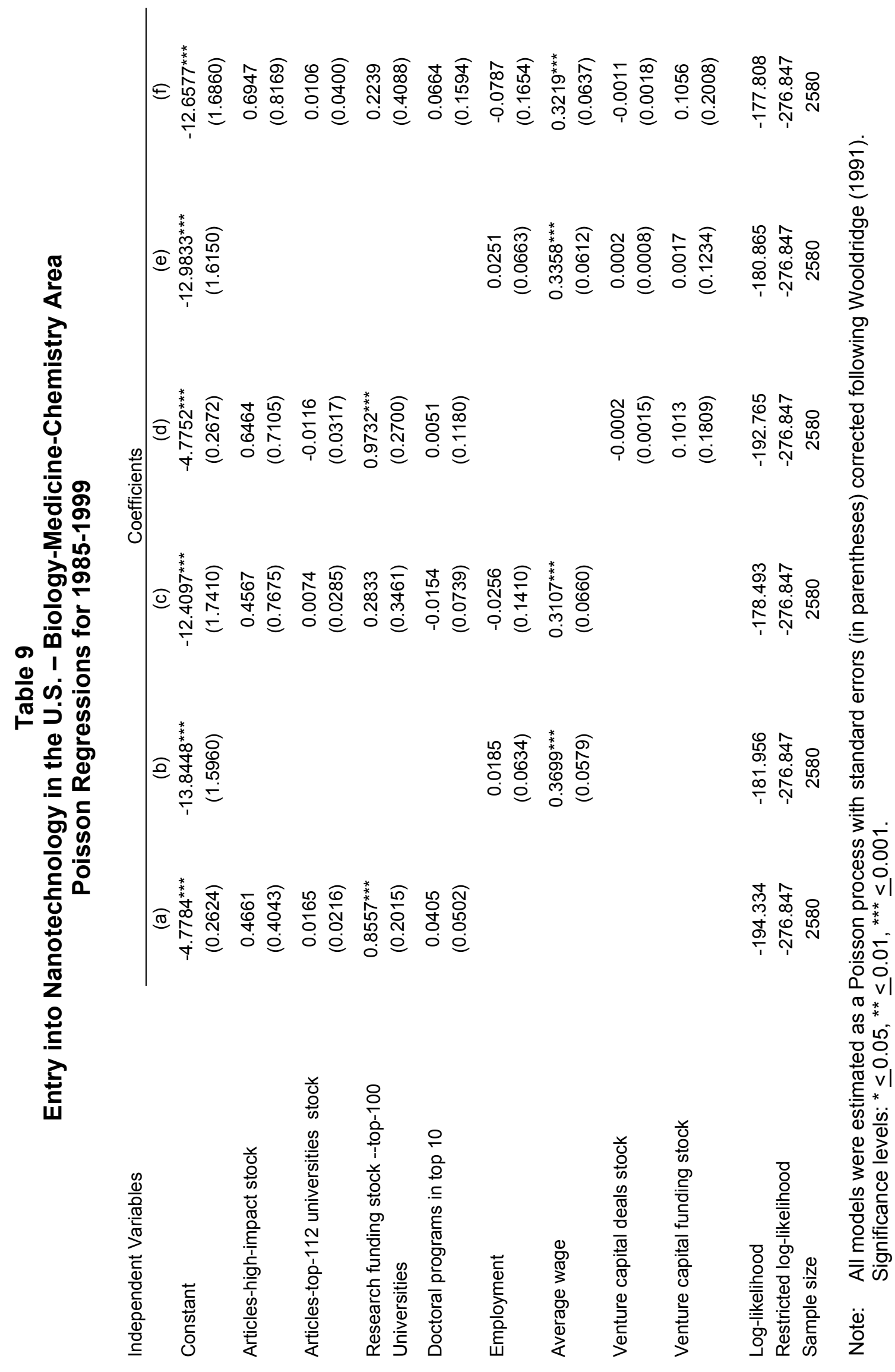




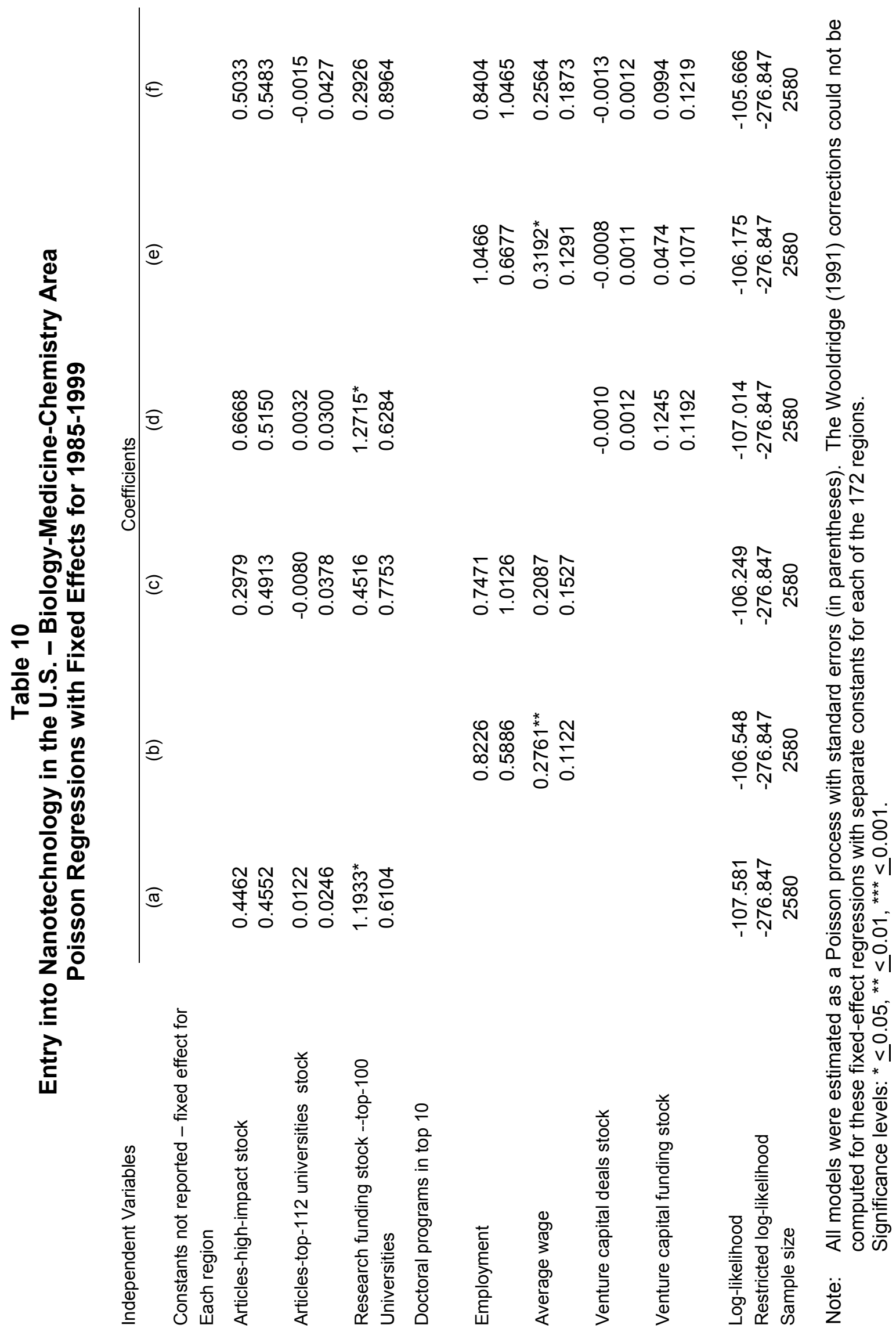




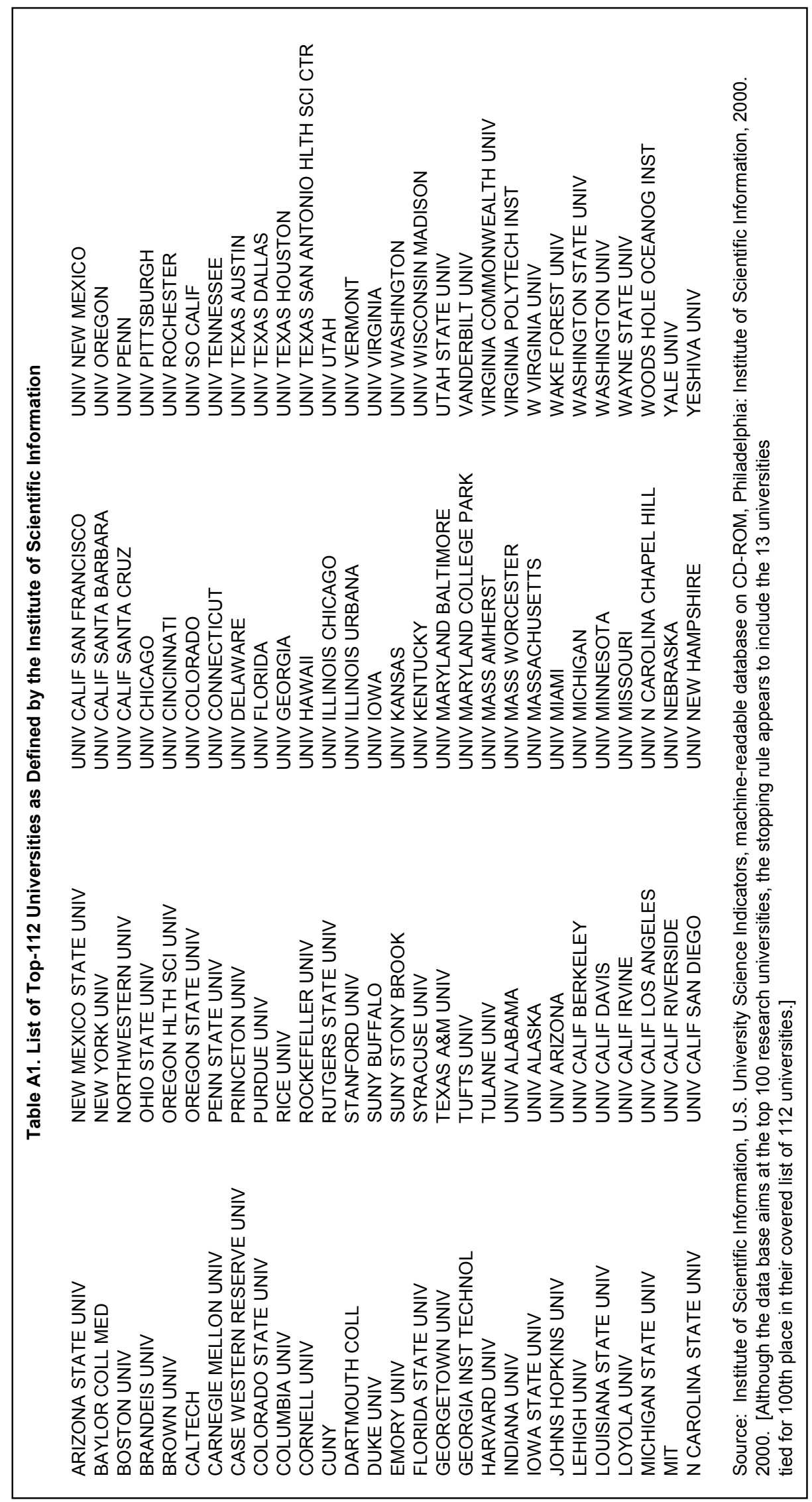


Table A2. Zucker-Darby S\&E Field Categorization and ISI Category Descriptions

\begin{tabular}{|c|c|}
\hline $\begin{array}{l}\text { Zucker-Darby } \\
\text { Categorization }\end{array}$ & ISI Journal Category Description \\
\hline $\begin{array}{l}\text { Biology/ } \\
\text { Medicine/ } \\
\text { Chemistry }\end{array}$ & $\begin{array}{l}\text { Agriculture/Agronomy, Anesthesia \& Intensive Care, Animal \& Plant } \\
\text { Sciences, Animal Sciences, Neurosciences \& Behavior, Biochemistry \& } \\
\text { Biophysics, Biology, Biotechnol \& Appl Microbiol, Cardiovasc \& Respirat } \\
\text { Syst, Cell \& Developmental Biol, Oncogenesis \& Cancer Res, Agricultural } \\
\text { Chemistry, Chemical Engineering, Chemistry \& Analysis, Chemistry, } \\
\text { Cardiovasc \& Hematology Res, Dentistry/Oral Surgery \& Med, } \\
\text { Dermatology, Medical Res, Diag \& Treatmt, Endocrinol, Nutrit \& Metab, } \\
\text { Entomology/Pest Control, Environment/Ecology, Experimental Biology, } \\
\text { Food Science/Nutrition, Gastroenterol and Hepatology, General \& Internal } \\
\text { Medicine, Hematology, Immunology, Inorganic \& Nucl Chemistry, Clin } \\
\text { Immunol \& Infect Dis, Molecular Biology \& Genetics, Microbiology, } \\
\text { Resrch/Lab Med \& Med Techn, Medical Res, General Topics, Neurology, } \\
\text { Endocrinol, Metab \& Nutrit, Medical Res, Organs \& Syst, Oncology, } \\
\text { Ophthalmology, Organic Chem/Polymer Sci, Orthopedics \& Sports Med, } \\
\text { Otolaryngology, Pediatrics, Physical Chem/Chemical Phys, Pharmacology \& } \\
\text { Toxicology, Plant Sciences, Pharmacology/Toxicology, Psychiatry, } \\
\text { Physiology, Clin Psychology \& Psychiatry, Radiol, Nucl Med \& Imaging, } \\
\text { Reproductive Medicine, Rheumatology, Environmt Med \& Public Hlth, } \\
\text { Surgery, Urology, and Veterinary Med/Animal Health }\end{array}$ \\
\hline $\begin{array}{l}\text { Computer/ } \\
\text { Information } \\
\text { Processing/ } \\
\text { Multimedia }\end{array}$ & $\begin{array}{l}\text { AI, Robotics \& Auto Control, Computer Sci \& Engineering, Engineering } \\
\text { Mathematics, Info Technol \& Commun Syst, and Mathematics }\end{array}$ \\
\hline $\begin{array}{l}\text { Integrated } \\
\text { Circuit/Semi- \& } \\
\text { Super-conductor }\end{array}$ & $\begin{array}{l}\text { Appl Phys/Cond Matt/Mat Sci, Elect \& Electronic Engn, Mechanical } \\
\text { Engineering, Metallurgy, Materials Sci and Engn, Optics \& Acoustics, Physics, } \\
\text { and Spectrosc/Instrum/Analyt Sci }\end{array}$ \\
\hline $\begin{array}{l}\text { Other } \\
\text { Engineering }\end{array}$ & $\begin{array}{l}\text { Aerospace Engineering, Civil Engineering, Environmt Engineering/Energy, } \\
\text { Engineering Mgmt/General, Geol/Petrol/Mining Engn, Instrumentation/ } \\
\text { Measurement, Nuclear Engineering, and Space Science }\end{array}$ \\
\hline Other Sciences & Aquatic Sciences, Earth Sciences, and Multidisciplinary \\
\hline
\end{tabular}

Source: Darby and Zucker (1999). 
Table A3. Zucker-Darby S\&E Field Categorization and NRC Standard Doctoral Programs

\begin{tabular}{|c|c|}
\hline \multicolumn{2}{|c|}{ Zucker-Darby Categorization and NRC standard programs } \\
\hline $\begin{array}{l}\text { Biology/ } \\
\text { Medicine/ } \\
\text { Chemistry }\end{array}$ & $\begin{array}{l}\text { Biochemistry \& Molecular Biology } \\
\text { Cell \& Developmental Biology } \\
\text { Molecular \& General Genetics } \\
\text { Ecology, Evolution \& Behavioral } \\
\text { Pharmacology } \\
\text { Chemistry } \\
\text { Biomedical Engineering } \\
\text { Chemical Engineering } \\
\text { Neurosciences } \\
\text { Physiology }\end{array}$ \\
\hline $\begin{array}{l}\text { Computer/ } \\
\text { Information } \\
\text { Processing/ } \\
\text { Multimedia }\end{array}$ & $\begin{array}{l}\text { Computer Sciences } \\
\text { Mathematics }\end{array}$ \\
\hline $\begin{array}{l}\text { Integrated } \\
\text { Circuit/Semi- } \\
\& \quad \text { Super- } \\
\text { conductor }\end{array}$ & $\begin{array}{l}\text { Physics } \\
\text { Electrical Engineering } \\
\text { Materials Science } \\
\text { Mechanical Engineering }\end{array}$ \\
\hline $\begin{array}{l}\text { Other } \\
\text { Engineering }\end{array}$ & $\begin{array}{l}\text { Aerospace Engineering } \\
\text { Civil Engineering } \\
\text { Industrial Engineering }\end{array}$ \\
\hline $\begin{array}{l}\text { Other } \\
\text { Sciences }\end{array}$ & $\begin{array}{l}\text { Oceanography } \\
\text { Astrophysics/Astronomy } \\
\text { Statistics/Biostatistics } \\
\text { Geosciences }\end{array}$ \\
\hline
\end{tabular}

Source: Darby and Zucker (1999). 


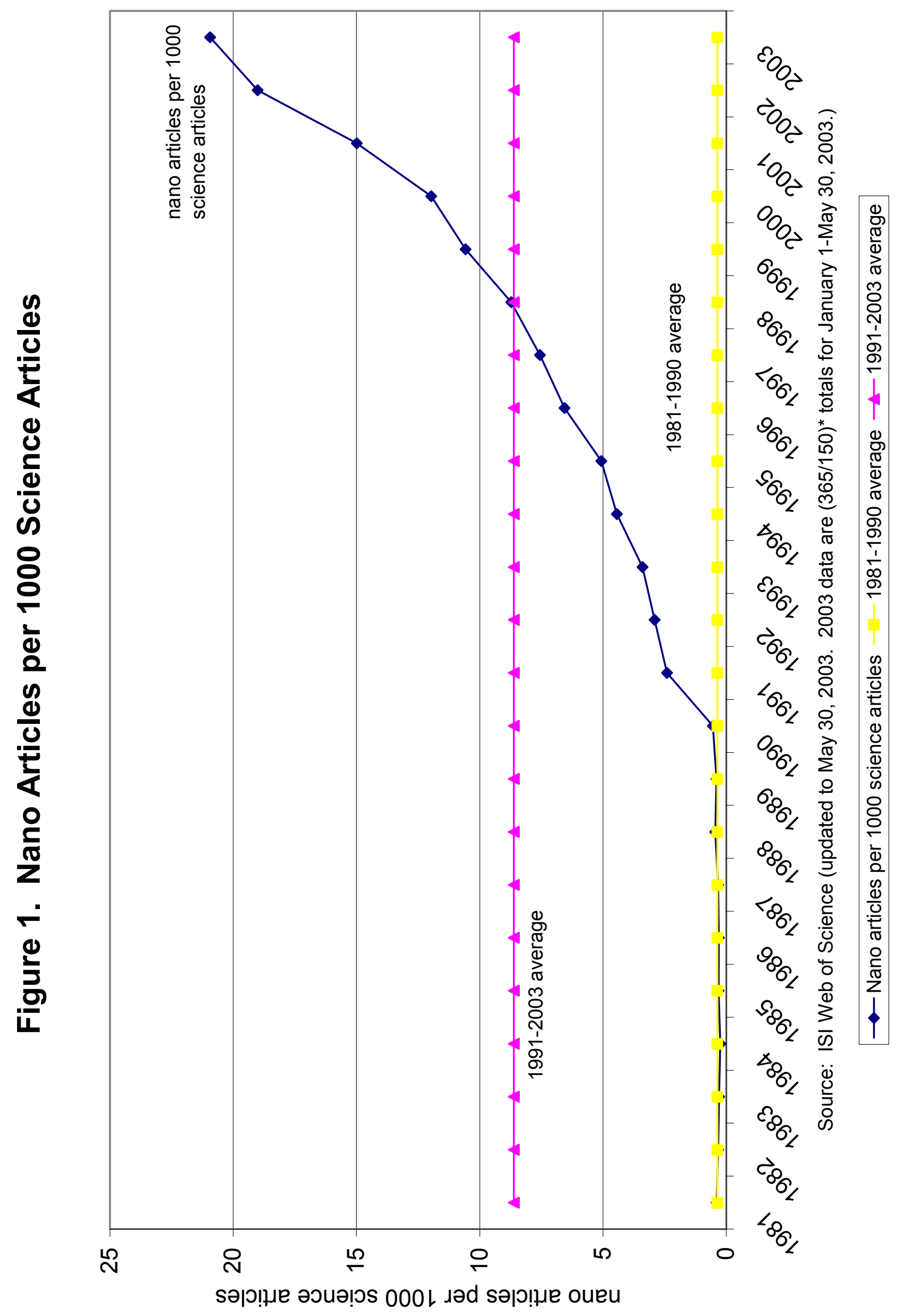




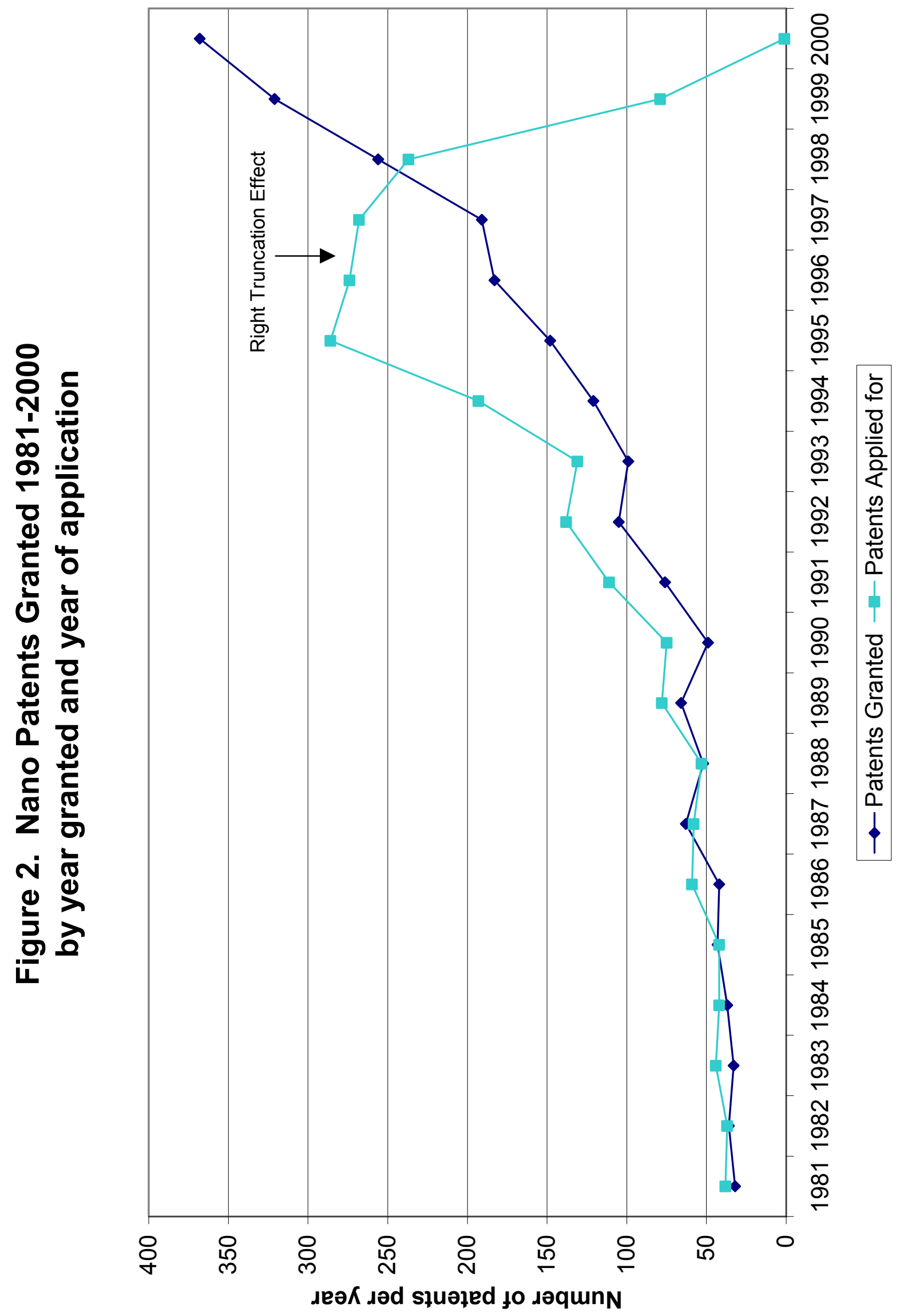



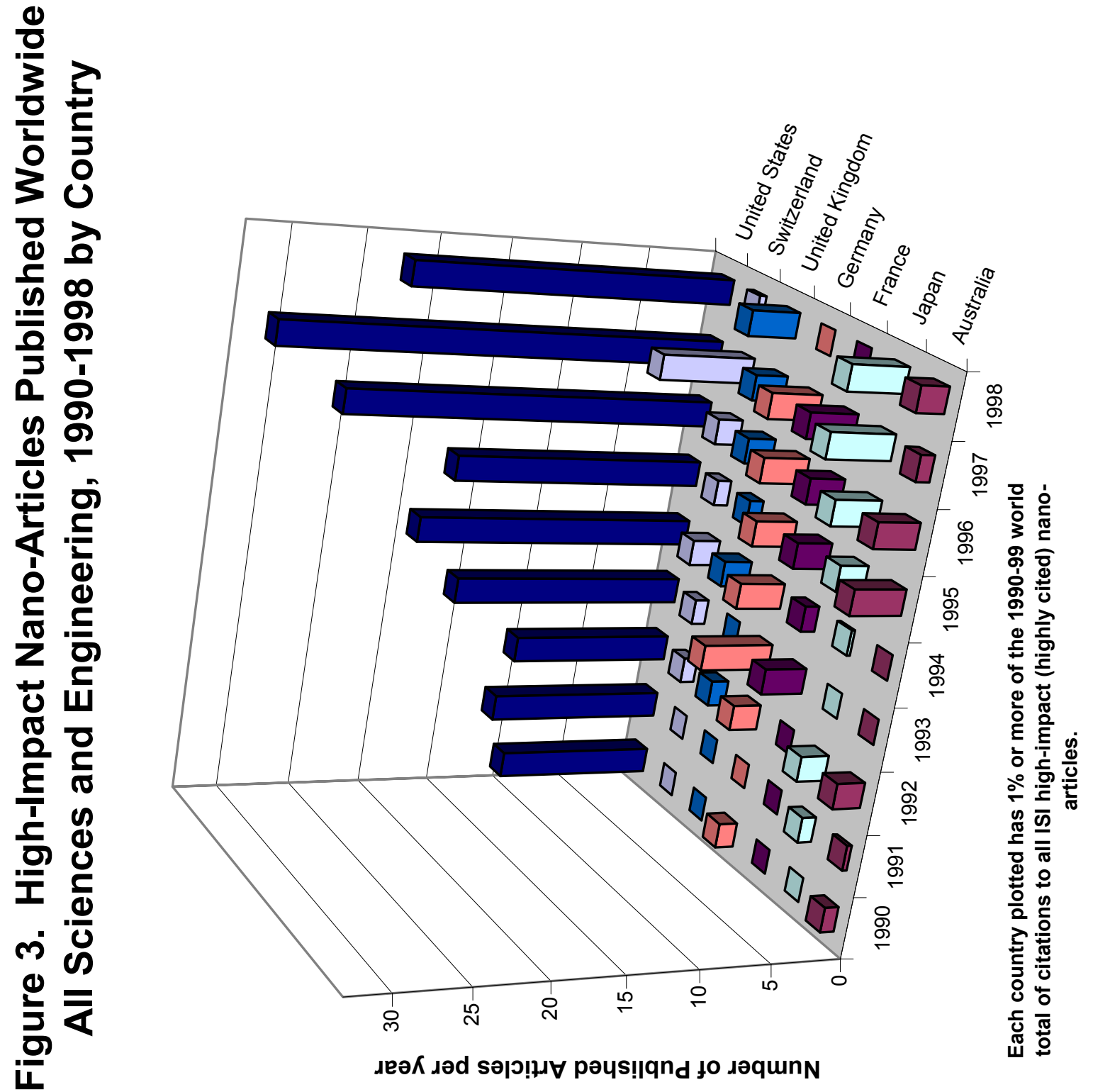


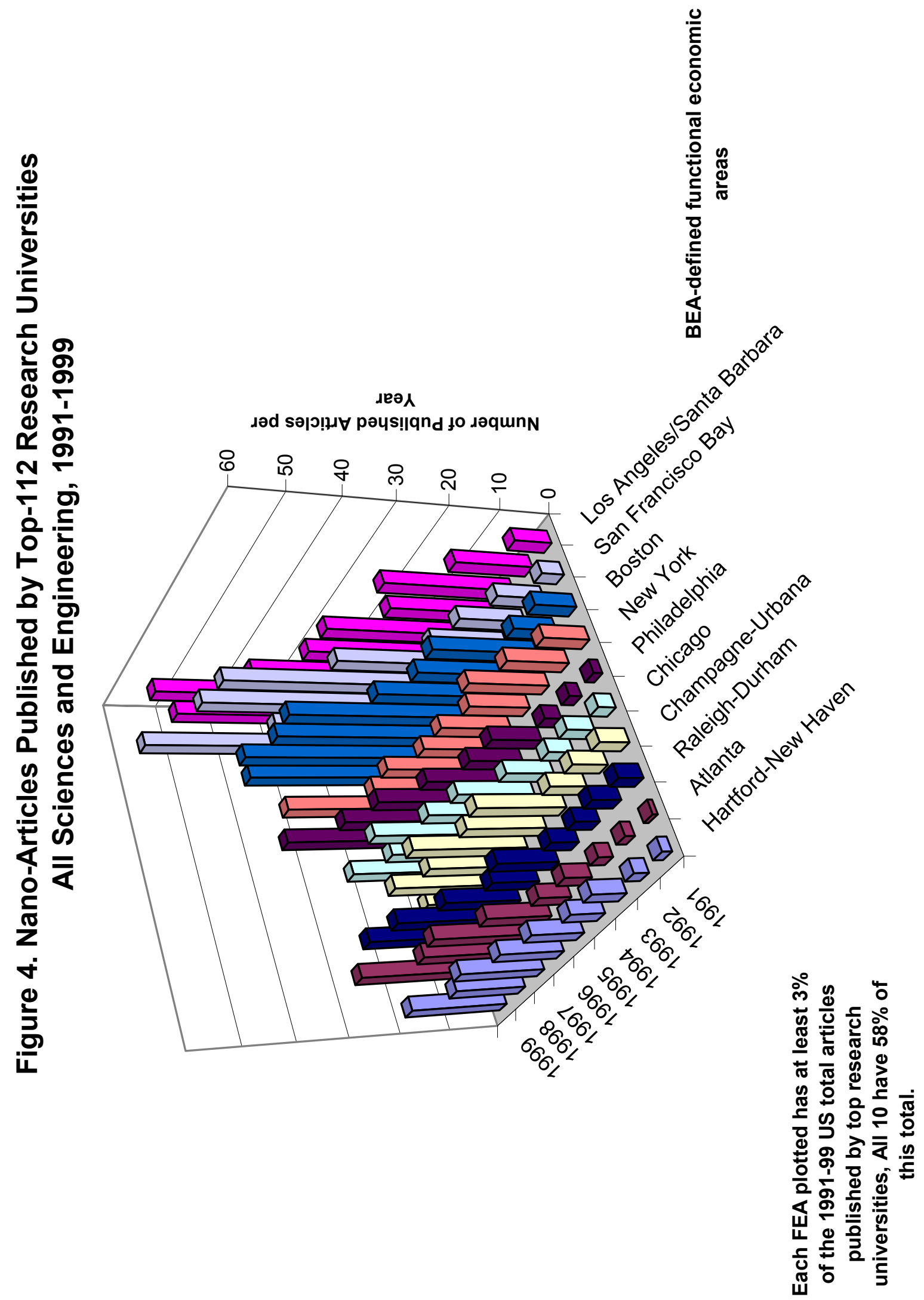




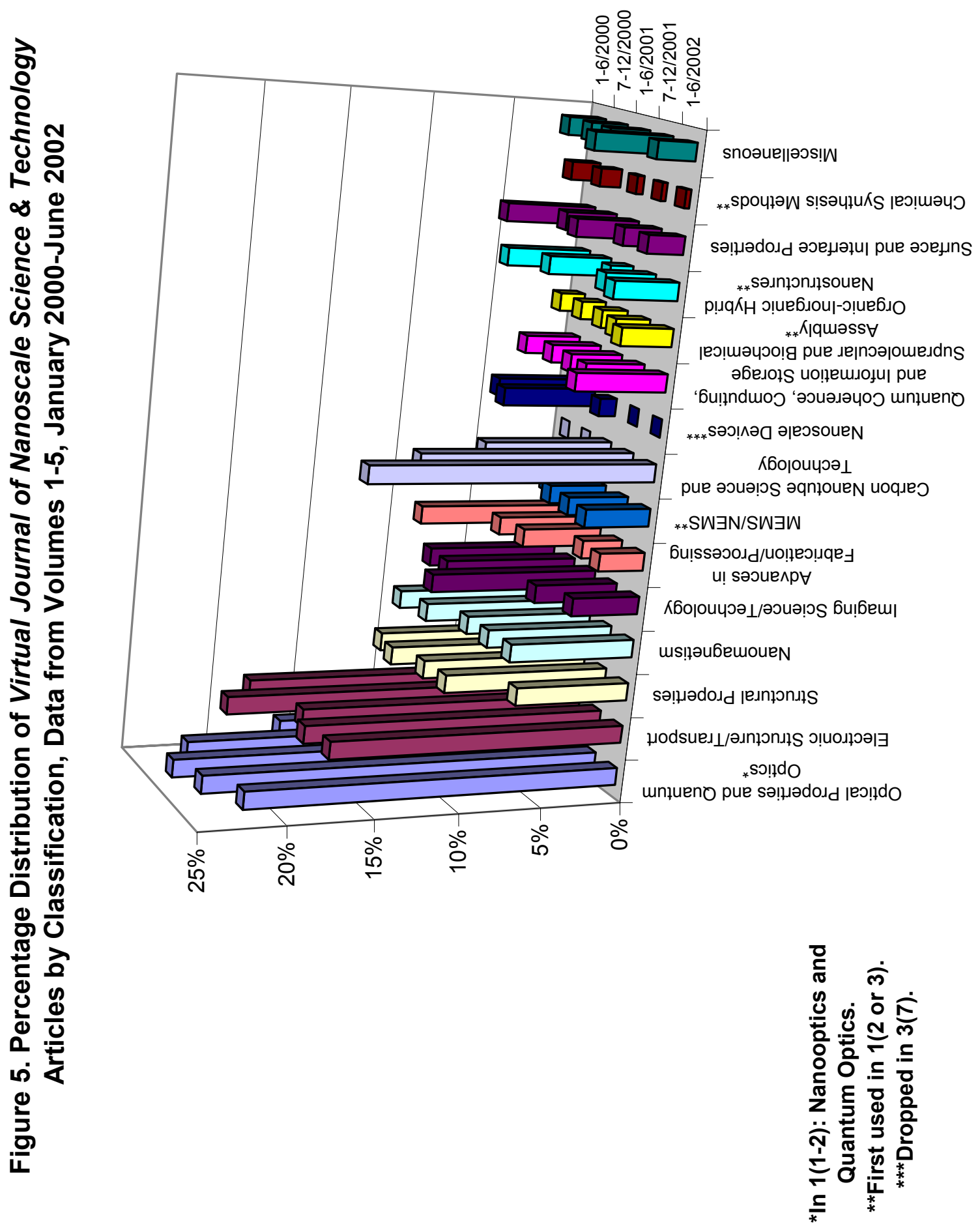




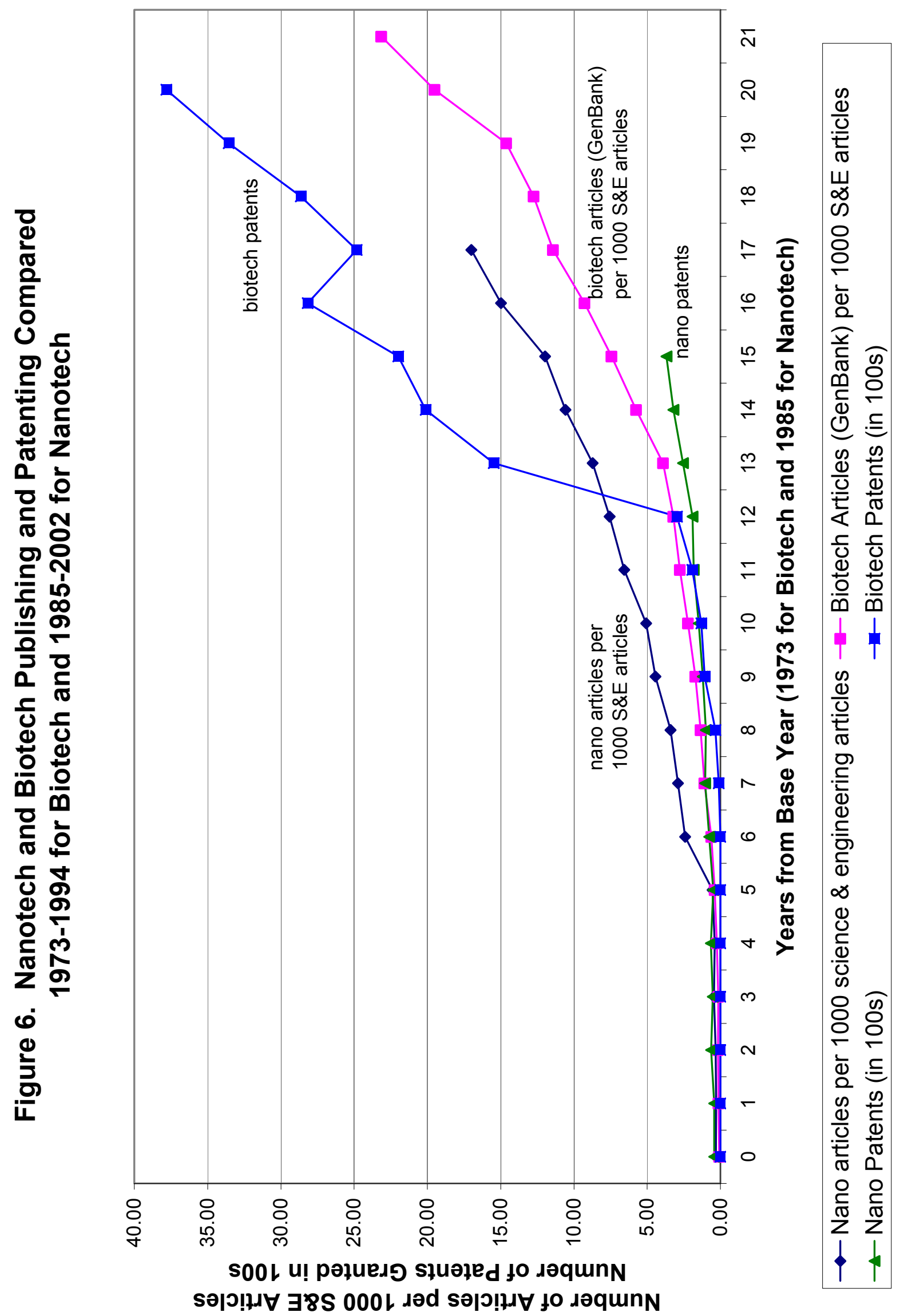




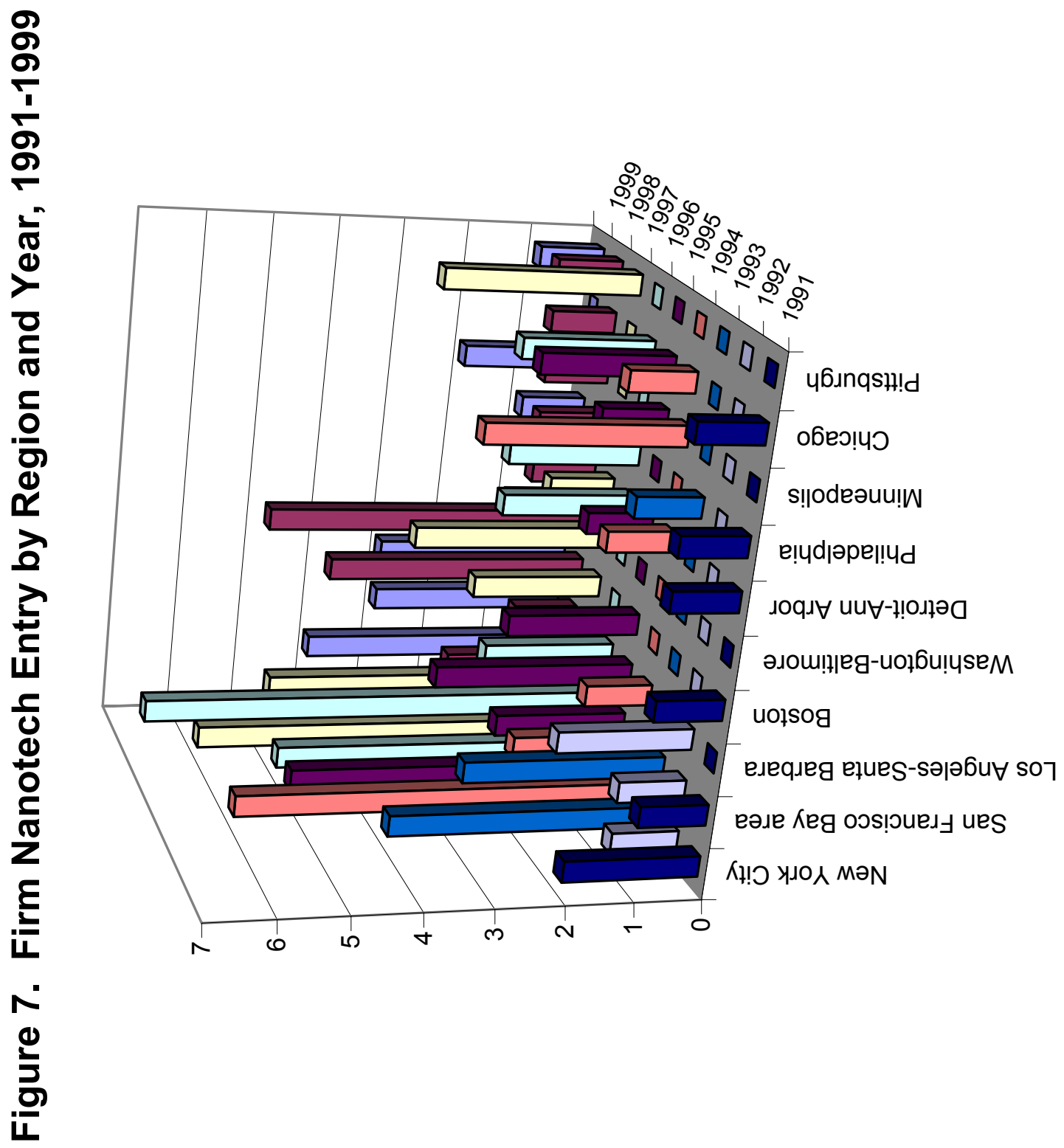




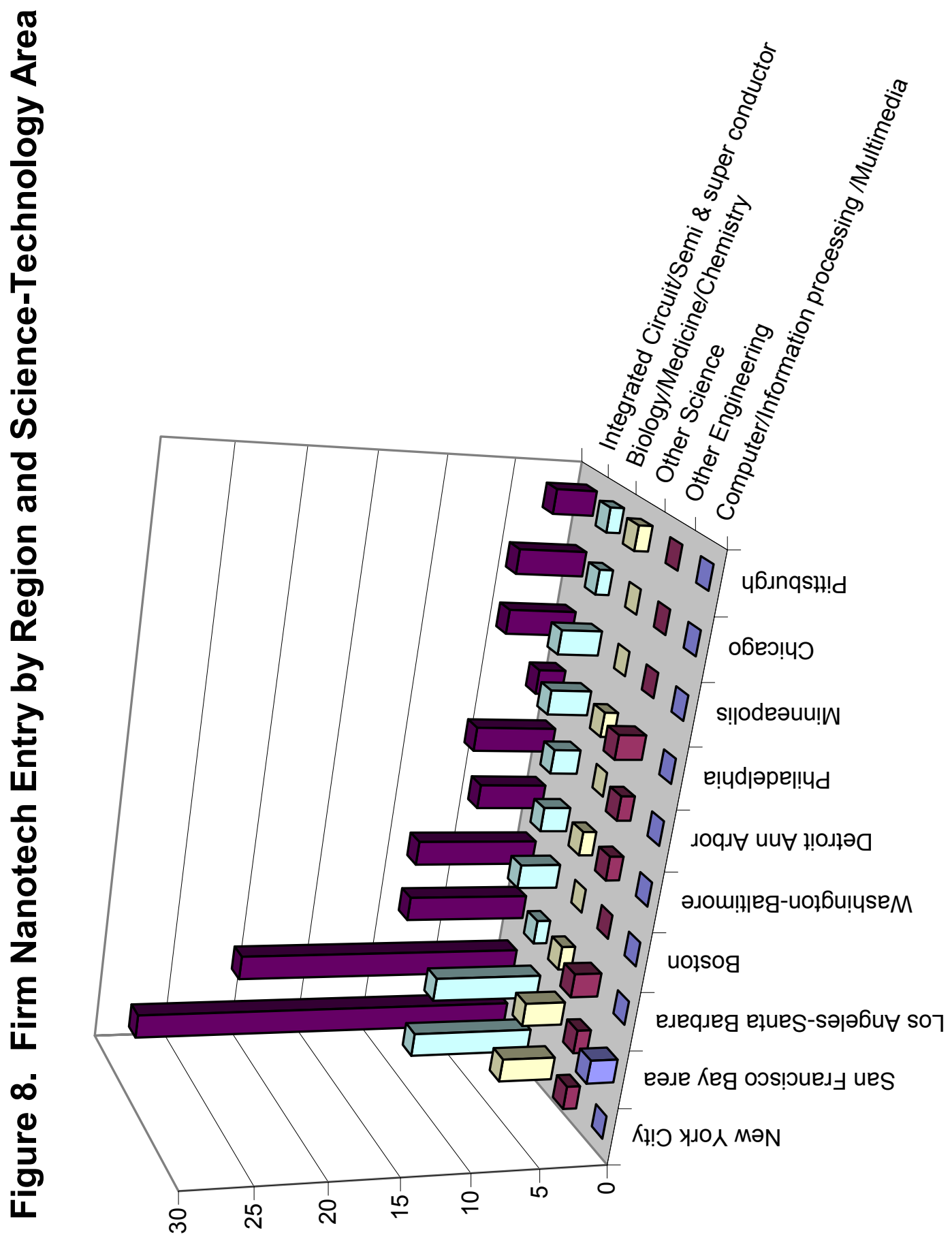

